\title{
Basement and Regional Structure Along Strike of the Queen Charlotte Fault in the Context of Modern and Historical Earthquake Ruptures
}

\author{
by Maureen A. L. Walton, Sean P. S. Gulick, Peter J. Haeussler, \\ Emily C. Roland, and Anne M. Tréhu
}

\begin{abstract}
The Queen Charlotte fault (QCF) is a dextral transform system located offshore of southeastern Alaska and western Canada, accommodating $4.4 \mathrm{~cm} / \mathrm{yr}$ of relative motion between the Pacific and North American plates. Oblique convergence along the fault increases southward, and how this convergence is accommodated is still debated. Using seismic reflection data, we interpret offshore basement structure, faulting, and stratigraphy to provide a geological context for two recent earthquakes, an $M_{\mathrm{w}} 7.5$ strike-slip event near Craig, Alaska, and an $M_{\mathrm{w}} 7.8$ thrust event near Haida Gwaii, Canada. We map downwarped Pacific oceanic crust near $54^{\circ} \mathrm{N}$, between the two rupture zones. Observed downwarping decreases north and south of $54^{\circ} \mathrm{N}$, parallel to the strike of the QCF. Bending of the Pacific plate here may have initiated with increased convergence rates due to a plate motion change at $\sim 6 \mathrm{Ma}$. Tectonic reconstruction implies convergence-driven Pacific plate flexure, beginning at 6 Ma south of a $10^{\circ}$ bend the QCF (which is currently at $53.2^{\circ} \mathrm{N}$ ) and lasting until the plate translated past the bend by $\sim 2 \mathrm{Ma}$. Normal-faulted approximately late Miocene sediment above the deep flexural depression at $54^{\circ} \mathrm{N}$, topped by relatively undeformed Pleistocene and younger sediment, supports this model. Aftershocks of the Haida Gwaii event indicate a normal-faulting stress regime, suggesting present-day plate flexure and underthrusting, which is also consistent with reconstruction of past conditions. We thus favor a Pacific plate underthrusting model to initiate flexure and accommodation space for sediment loading. In addition, mapped structures indicate two possible fault segment boundaries along the QCF at $53.2^{\circ} \mathrm{N}$ and at $56^{\circ} \mathrm{N}$.
\end{abstract}

Introduction

Offshore of southeast Alaska and western British Columbia, the $750 \mathrm{~km}$ long Queen Charlotte fault (QCF) is the primary Pacific-North American plate boundary fault, accommodating relative dextral offset of $4.4 \mathrm{~cm} / \mathrm{yr}$ (Fig. 1; Elliott et al., 2010). The fault is obliquely convergent along strike, with maximum convergence south of a bend in the $\mathrm{QCF}$ at $53.2^{\circ} \mathrm{N}$. The northern QCF strikes at $338^{\circ}$ (Rohr et al., 2000) and offshore of southeastern Alaska becomes the Fairweather fault, resulting in a $1200 \mathrm{~km}$ long onshore/offshore right-lateral transform zone (Fig. 1; Fletcher and Freymueller, 2003). The junction of the Queen Charlotte, Fairweather, and Transition faults is located at the southeastern tip of the Yakutat block, an oceanic plateau and microplate (Fig. 1; Gulick et al., 2007; Christeson et al., 2010). The southern boundary of the QCF is marked by the complex Pacific-North American-Explorer triple junction off the coast of southern British Columbia (Fig. 1; Rohr and Furlong, 1995; Rohr, 2015). South of $53.2^{\circ} \mathrm{N}$, near Haida Gwaii, the strike of the $\mathrm{QCF}$ is $328^{\circ}, \sim 10^{\circ}$ less than the northern QCF, creating oblique convergence between the plates and a structural regime similar to a restraining bend along the southern QCF (Fig. 1; Rohr et al., 2000).

There have been several strike-slip earthquakes with a magnitude larger than 7 along the Queen CharlotteFairweather fault system in the last century (Fig. 1). The earliest recorded large event was a magnitude 7.1 earthquake on the southeast QCF in 1927 (Tobin and Sykes, 1968). In 1949, the largest recorded earthquake in Canada occurred when an estimated $470 \mathrm{~km}$ long section (Rogers, 1986) of the southern and central QCF slipped to produce an $M_{\mathrm{s}} 8.1$ earthquake (Sykes, 1971). The extent of the 1949 rupture area is debated and poorly constrained due to difficulties in interpreting the aftershock sequence and disagreement with surface-wave directivity analysis. A study by Bostwick (1984) proposes two models for the 1949 event: a longer, bilateral rupture model based on aftershocks and a shorter, northward-propagating rupture based on surface-wave directivity (see fig. 3 from Tréhu et al., 2015, for a summary of different rupture models for the 1949 event). Recent Global Positioning System (GPS) analysis of seismicity supports the latter, shorter rupture model 


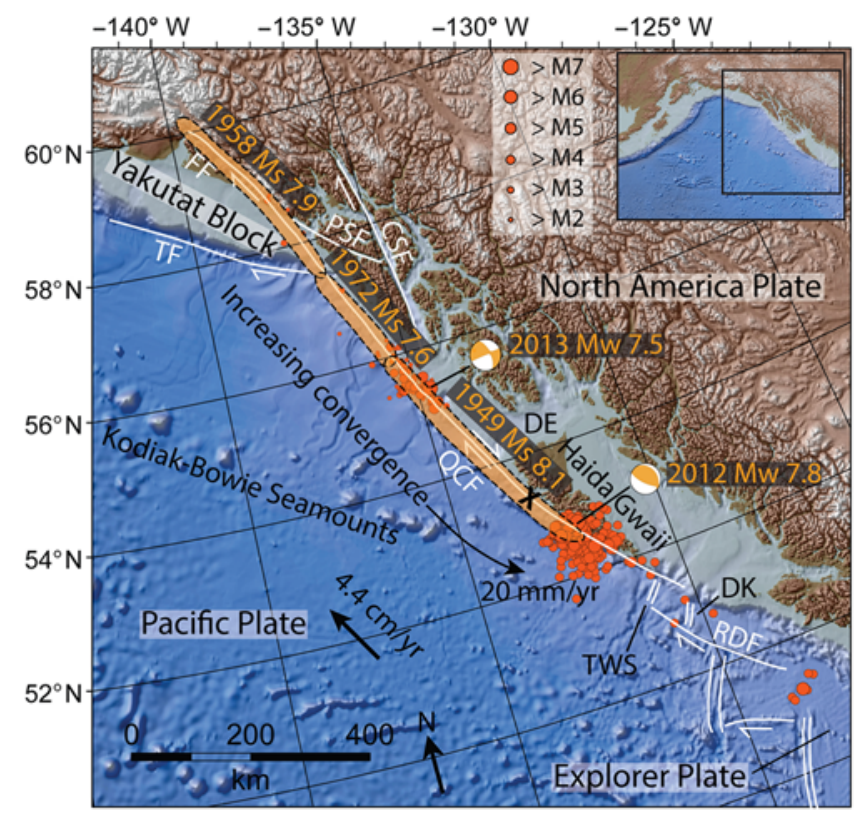

Figure 1. Regional tectonic setting of the Queen Charlotte fault (QCF), including major fault traces. The inset shows regional location. Because of the angle of the Pacific plate vector and the geometry of the QCF, convergence along the fault increases to the south. The bold X on the QCF marks a $10^{\circ}$ change in strike of the QCF at $53.2^{\circ} \mathrm{N}$, south of which is an obliquely convergent segment of the QCF undergoing convergence rates up to $\sim 20 \mathrm{~mm} / \mathrm{yr}$. The QCF is bounded to the north by the Yakutat block and to the south by the Explorer triple junction. Rupture zones defined by aftershocks for major historic earthquakes along the margin are indicated by dashed black outlines (Plafker et al., 1994). Aftershocks (circles) and focal mechanisms for the $2013 M_{\mathrm{w}} 7.5$ Craig earthquake and the 2012 $M_{\mathrm{w}} 7.8$ Haida Gwaii earthquake are also included, along with a magnitude scale for aftershocks (derived from the Global Centroid Moment Tensor catalog; Ekström et al., 2012; see Data and Resources). DE, Dixon Entrance; TWS, Tuzo Wilson seamounts; DK, Dellwood Knolls; TF, Transition fault; FF, Fairweather fault; PSF, Peril Strait fault; CSF, Chatham Strait fault. The color version of this figure is available only in the electronic edition.

for the 1949 event (Ding et al., 2015). Subsequent to the 1949 event, an $M_{\mathrm{s}} 7.9$ earthquake in 1958 ruptured $280 \mathrm{~km}$ of the Fairweather fault (Tocher, 1960; Plafker et al., 1978), and an $M_{\mathrm{s}} 7.6$ earthquake ruptured near Sitka in 1972 along the central QCF (Schell and Ruff, 1989).

Two recent large earthquakes have brought increased interest to the fault structure along the QCF. On 28 October 2012, an $M_{\mathrm{w}} 7.8$ earthquake occurred just offshore and south of Moresby Island, Canada (southern Haida Gwaii; Fig. 1). This earthquake (the Haida Gwaii earthquake) occurred on a thrust fault with some oblique slip, striking north-northwest $\sim 320^{\circ}$ and dipping $\sim 18.5^{\circ}$ to the east; it ruptured $\sim 150 \mathrm{~km}$ of a fault at $14 \mathrm{~km}$ depth, with an average $\sim 3.3 \mathrm{~m}$ of slip (James et al., 2013; Lay et al., 2013; U.S. Geological Survey [USGS], see Data and Resources). On 5 January 2013 and $330 \mathrm{~km}$ northwest of the Haida Gwaii epicenter, an $M_{\mathrm{w}} 7.5$ event occurred $95 \mathrm{~km}$ west of Craig, Alaska (Fig. 1). The Craig earthquake demonstrated significantly different source properties, with a right-lateral strike-slip mechanism. This event ruptured an $\sim 50 \mathrm{~km}$ segment of the QCF, striking $335^{\circ}$ on a subvertical fault plane dipping $63^{\circ}$ to the east. Maximum slip was estimated at 7-8 m (USGS, see Data and Resources). The Craig earthquake is similar in mechanism and magnitude to many of the historic strike-slip events along the QCF. The Haida Gwaii event was exceptional because it was significantly larger in moment magnitude than other thrust events along the transpressional southern QCF system (Ristau et al., 2007; Rabinovich et al., 2008). It was followed by normal-faulting aftershocks within the Pacific plate, likely generated from bending of the Pacific plate in response to underthrusting (Lay et al., 2013; Kao et al., 2015).

Because of active seismicity and its similarity to other large-scale strike-slip systems, study of the QCF system is important for assessing the hazard to communities located near the fault, as well as for better understanding of oceancontinental transform systems. The QCF system is comparable to the San Andreas in terms of length and moment release (e.g., Carlson et al., 1988; Freymueller et al., 1999), yet it has been much less studied. In this study, we compile and analyze publicly available marine geophysical data to provide regional-scale interpretations of crustal and fault structure along the entire strike of the QCF system. Specifically, we map areas of basement flexure, buried offshore normal faulting, and modern fault geometry. We observe downwarping of the Pacific plate north of $53.2^{\circ} \mathrm{N}$ and suggest that this flexure is a remnant of, and evidence for, past convergence south of $53.2^{\circ} \mathrm{N}$. By putting earthquake ruptures along the margin into the context of our observations, we also provide evidence for two possible fault segment boundaries along the QCF, one at $53.2^{\circ} \mathrm{N}$ and the other at $56^{\circ} \mathrm{N}$.

\section{Queen Charlotte Fault Geometry and Convergence}

Prior to the current phase of Pacific-North American plate motion, the QCF system had a varied history. The system began at the time of a major plate reorganization in the Pacific at $\sim 50$ Ma (Haeussler et al., 2003). After a period of oblique extension from $\sim 36$ to $20 \mathrm{Ma}$ (Hyndman and Hamilton, 1993; Morozov et al., 1998), a plate motion change at $20 \mathrm{Ma}$ resulted in the Yakutat block beginning to travel with the Pacific plate (Hyndman and Hamilton, 1993). This event is generally interpreted to be the beginning of strike-slip motion on the QCF (Atwater, 1970; Carlson et al., 1988), and it has remained a strike-slip fault since $20 \mathrm{Ma}$ (Crouch et al., 1984). Oblique convergence along the QCF is thought to have begun in the late Miocene or early Pliocene due to a small change in Pacific plate motion. The exact timing of the change is debated (e.g., von Huene et al., 1979; Hyndman and Hamilton, 1993; Wilson, 2002; Smith et al., 2003), although recent modeling places the change at $6 \mathrm{Ma}$ (Doubrovine and Tarduno, 2008), the age we assume for this study. The geometry of the QCF is important when considering local restraining and releasing bends; today, oblique convergence is highest along the QCF south of a restraining 
right step at $53.2^{\circ} \mathrm{N}$ (Fig. 1). Based on structural analysis, Tréhu et al. (2015) suggest that the change in strike of the QCF at $53.2^{\circ} \mathrm{N}$ significantly affects the response of the Pacific plate upper crust and overlying sediments to transpression, with pure shear dominant to the south and simple shear dominant to the north. The results of this study are consistent with this idea.

The Haida Gwaii earthquake can be explained by oblique convergence along the southern QCF where the component of convergence is $15-20 \mathrm{~mm} / \mathrm{yr}$ as predicted by MORVEL (DeMets et al., 2010; Tréhu et al., 2015; see also Data and Resources). A maximum 100-120 km of convergence based on a $20 \mathrm{~mm} / \mathrm{yr}$ rate must have been accommodated along the QCF over the last 5-6 Ma (Crouch et al., 1984; Hyndman and Hamilton, 1993). Many questions still exist concerning lithospheric and fault structure of the QCF and how shortening is accommodated in the crust, especially along the southernmost QCF where the convergence rate is highest.

Convergence along the southern QCF, accommodated by underthrusting of the Pacific plate beneath Haida Gwaii, has been proposed in the past (e.g., Hyndman et al., 1982; Hyndman and Hamilton, 1993). Evidence for underthrusting includes the presence of the Queen Charlotte Trough west of Haida Gwaii, a sedimentary complex similar to an accretionary prism (the Queen Charlotte terrace [QCT]), coastal uplift, heat flow measurements, and a dipping low velocity anomaly at depth east of the QCF thought to represent oceanic crust (Bustin et al., 2007). These features are all consistent with incipient subduction. Models have also been proposed in which all convergence is accommodated by shortening via thrust faulting on either side of the QCF extending through the crust (Hyndman and Ellis, 1981; Rohr et al., 2000). This model requires at least $80 \mathrm{~km}$ of crustal shortening (assuming a 4 my duration of $20 \mathrm{~mm} / \mathrm{yr}$ convergence) over a width of 30-60 km within both the Pacific and North American plates (Crouch et al., 1984; Rohr et al., 2000), which is similar to the 14-72 km of transpression taken up along the San Andreas fault (Crouch et al., 1984). In this latter case, the Queen Charlotte Trough could be explained by plate flexure due primarily to sediment loading on the Pacific plate (Prims et al., 1997) and does not require an additional load from the Pacific plate underthrusting the North American plate east of the QCF (Harris and Chapman, 1994).

The source properties of the recent Haida Gwaii earthquake, as well as aftershock behavior and information on coseismic deformation, shed more light on convergence models for southern Haida Gwaii and seem to support a model that incorporates underthrusting of the Pacific plate (e.g., Lay et al., 2013; Nykolaishen et al., 2015). The Haida Gwaii mainshock hypocenter was located $7 \mathrm{~km}$ landward of the QCF main trace, at a depth corresponding with the lower end of the seismogenic zone of an underthrust Pacific plate (Kao et al., 2015). A tsunami with up to $\sim 13$ m runup also indicates a significant component of underthrusting and slip (Leonard and Bednarski, 2014). Normal-faulting aftershocks in the Pacific plate suggest plate bending and downdip extension, consistent with young subduction (Lay et al., 2013; Farahbod and Kao, 2015; Kao et al., 2015). GPS data and new thermal models are consistent with these interpretations, supporting a shallow megathrust event (Nykolaishen et al., 2015; Wang et al., 2015). Although these recent results strongly support underthrusting in the Haida Gwaii region, some amount of crustal shortening in the continental and/or oceanic plates has almost certainly taken place, given the complex fault patterns and deformation along strike of the QCF. The question of how much shortening versus underthrusting has taken place is a topic of ongoing debate and research.

In this study, we observe an inactive flexural system north of Haida Gwaii and hypothesize that it is a remnant of a similar system currently observable to the south, suggesting that the now inactive system underwent convergence along the southern QCF before translating past it. We present a hybrid model that can accommodate elements of both underthrusting and crustal shortening, with Pacific plate flexure initiated by underthrusting and preserved by sediment loading.

\section{Methods}

\section{Data}

Seismic reflection data available through the USGS (Fig. 2) was used for the bulk of our interpretations. Twodimensional USGS seismic surveys crossing offshore faults include L-5-77-EG (1977), L-3-78-EG (1978), S-5-78-EG (1978), S-6-79-GA (1979), and F-7-89-EG (1989). Each of these surveys was used in this study for mapping faults and basement structure. S-5-78-EG (Carlson et al., 1985) was one of the original surveys used to map the QCF north of $56^{\circ} \mathrm{N}$, and we compare our new mapping to these original results. Surveys L-5-77-EG and L-3-78-EG are high-resolution surveys employing a 24-channel streamer, with seismic lines crossing the QCF several times along strike, covering the northern half of Haida Gwaii and the Dixon Entrance. These two surveys were integral to this study, and several figures presented here display data from these surveys. Surveys S-6-79-GA and F-7-89-EG were used in this study, primarily for basement mapping. S-6-79-GA is a deep-water USGS survey that crosses the northern QCF. F-7-89-EG was shot as part of the Geological LOng-Range Inclined Asdic (GLORIA) project conducted by the USGS and the Institute of Oceanographic Sciences (now the Southampton Oceanography Center; see Data and Resources) in an effort to better define the United States exclusive economic zone. GLORIA surveys were primarily designed to obtain sidescan sonar data coverage of the Gulf of Alaska, but two-channel seismic reflection data were also collected (Bruns et al., 1992). Data are quite sparse along the southern QCF off of central Haida Gwaii; survey F-7-89-EG is one of the few constraints that we have on basement structure in this region, so data from other studies support interpretations here.

Academic survey EW9412, shot as a part of the ACCRETE project (e.g., Scheidhauer et al., 1999; see also Data 


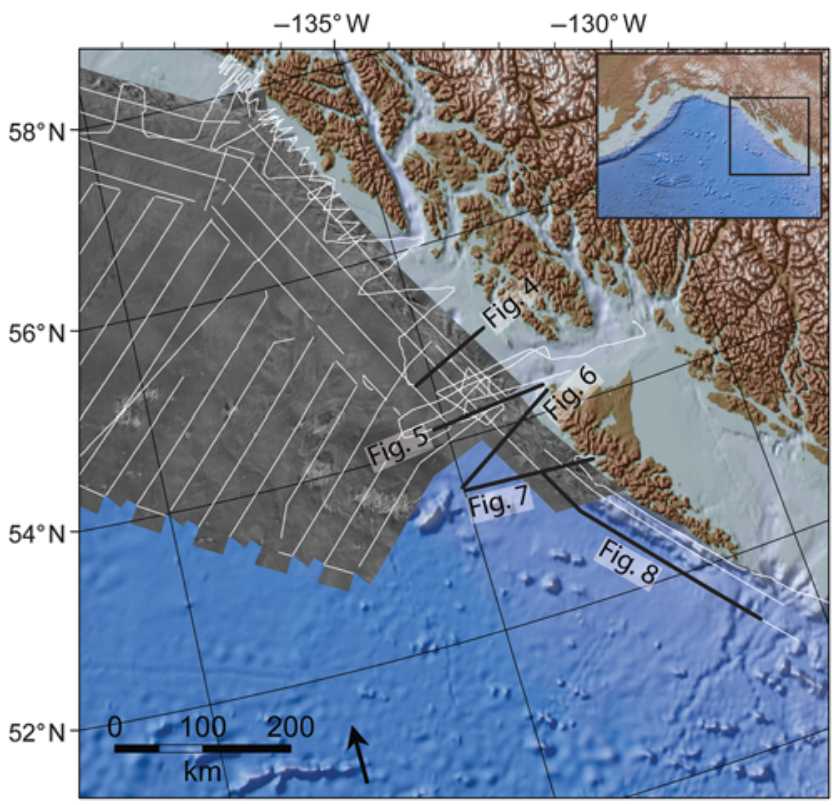

Figure 2. Data coverage map showing ETOPO1 bathymetry as the background image (Amante and Eakins, 2009), GLORIA sidescan sonar data overlaid on top of the bathymetry, and U.S. Geological Survey (USGS) and academic 2D seismic reflection surveys that cross the QCF are displayed as white lines. Plotted surveys include USGS surveys L-5-77-EG, L-3-78-EG, S-5-78-EG, S-6-79GA, and F-7-89-EG, and academic survey EW9412. For this study, basement and fault mapping were completed on lines from all surveys. Sections shown in other figures are highlighted with their figure numbers labeled. The inset shows regional location. The color version of this figure is available only in the electronic edition.

and Resources), is one of the better-quality marine seismic datasets crossing the QCF, with five 2D seismic reflection lines covering the area just north of Haida Gwaii at the Dixon Entrance (Fig. 2). The survey was collected aboard the $R / V$ Maurice Ewing in 1994. Processing was completed by M. Scheidhauer (Scheidhauer, 1997; Scheidhauer et al., 1999). This survey was important for interpretation of faults and basement structure in the area, and examples of the EW9412 profiles can be seen in Rohr et al. (2000) and Tréhu et al. (2015).

In addition to the coincident seismic data, GLORIA sidescan sonar data were used (Fig. 2) to map the seafloor trace of the QCF. The QCF has previously been mapped using the $50 \mathrm{~m}$ resolution GLORIA data (e.g., Bruns et al., 1992). In this study, the seafloor expression of the fault has been remapped using the GLORIA dataset and compared with fault-crossing seismic reflection data. In addition to the GLORIA data, there is high-resolution $\left(\sim 100 \mathrm{~m}^{2}\right)$ multibeam bathymetry coverage along the continental slope and rise of the northern and central QCF from the United Nations Commission Law of the Sea (UNCLOS; Gardner et al., 2006). These data are not quite as effective as the GLORIA data for mapping the QCF on the seafloor due to their lower resolution. The $100 \mathrm{~m}$ resolution UNCLOS data were merged with ETOPO1 1 arc-min global relief data (Amante and Eakins, 2009; see also Data and Resources) and used primarily as a background map for refer-

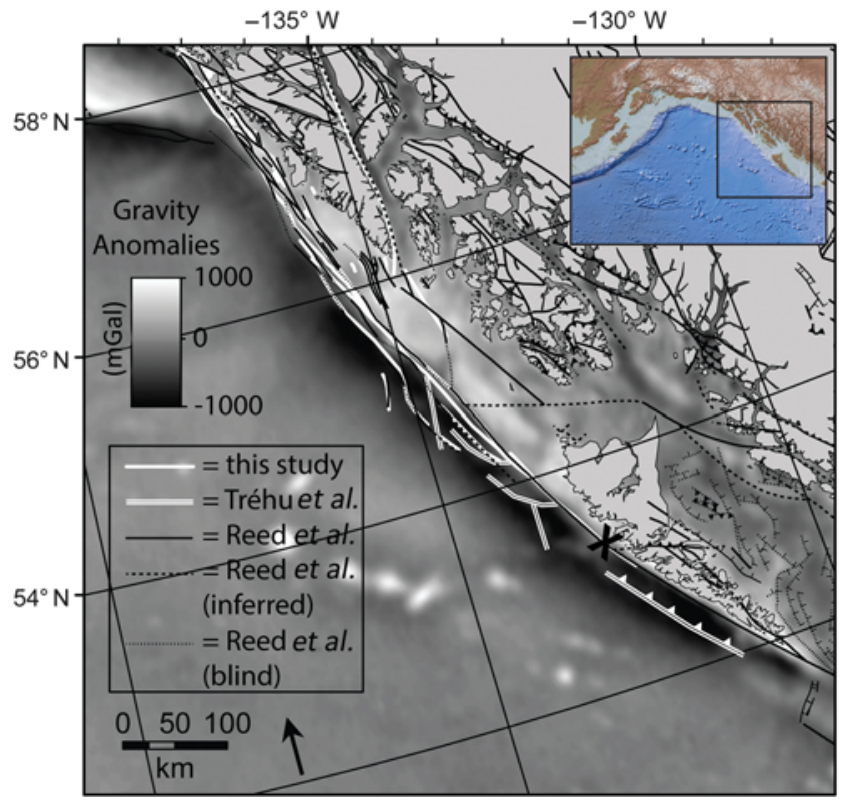

Figure 3. Background image shows grayscale gridded gravity anomalies (Sandwell et al., 2013) with the modern coastline for reference. New Quaternary fault mapping from this study (thick white lines) and the faults proposed by Tréhu et al. (2015; double white lines) are also plotted, along with a compilation of previously mapped faults in the area (Reed et al., 2005; thinner black lines). Inferred faults from Reed et al. (2005) are plotted with black dashed lines and blind faults (Reed et al., 2005) with black stippled lines. Bold black X marks a change in strike along the QCF. New mapping from this study is based on USGS seismic reflection profiles and GLORIA data. Agreement between the new mapping and the Reed et al. (2005) database is good where USGS data exist. The inset shows regional location. The color version of this figure is available only in the electronic edition.

ence. The southernmost QCF has new, high-resolution multibeam coverage and is discussed in a study by Barrie et al. (2013) and Rohr (2015).

Gridded magnetic and gravity datasets also complement seismic reflection data and provide a regional picture of basement character and age. Gridded magnetic anomalies were acquired from the EMAG2 model, compiled by the National Geophysical Data Center (NGDC; Maus et al., 2009). These anomalies combined with isochron maps of Müller et al. (1997) provide age estimates for the Pacific basement adjacent to the QCF. Recently updated gridded gravity anomalies (Fig. 3) from Sandwell et al. (2013) also give insight into regional changes in sediment thickness and basement structure.

\section{Analysis}

The analysis presented here required mapping of the seafloor and subsurface geophysical data, and various techniques were used. The seafloor geometry of the QCF was visualized primarily using GLORIA sidescan data in Halliburton's Landmark DecisionSpace Desktop software (see Data and Resources). This seafloor mapping was verified using available 2D seismic datasets. Comparing the sidescan sonar and seismic reflection data allowed characterization of 
the bathymetric expression and internal character of the QCF along strike.

In addition to faults, regional stratigraphic surfaces were mapped in the sediment offshore of Haida Gwaii and the Dixon Entrance using DecisionSpace Desktop. Two surfaces (SEAK1 and SEAK2) were mapped based on disconformities visible in seismic reflectors. Both surfaces exhibit onlap relationships. The surface of the Pacific basement rock, recognizable by high-amplitude, semicontinuous seismic reflectors, was also mapped. The Pacific basement surface was gridded and interpolated at $1 \mathrm{~km}$ resolution in DecisionSpace Desktop and exported to be analyzed in Esri's ArcGIS software (see Data and Resources).

Gridded surfaces, including global gravity (Sandwell et al., 2013), magnetics (Maus et al., 2009), seafloor age (Müller et al., 1997), global bathymetry (Amante and Eakins, 2009), and depth to Pacific basement were compiled into ArcGIS. Gridded data were then analyzed and compared with new maps of the QCF (also exported from DecisionSpace Desktop), offshore faults, and historic earthquake rupture areas to supplement observations and interpretations. Gridded horizons interpreted on seismic data are displayed in two-way travel time (TWTT) instead of thickness for accuracy and consistency, as velocity information is not available for many of the 2D transects used in this study. Dips on faults and surfaces were calculated using a sediment velocity of $2000 \mathrm{~m} / \mathrm{s}$ in the sediment column and $2200 \mathrm{~m} / \mathrm{s}$ at the basement surface, similar to the sediment column value used by Walton et al. (2014) for the study of deep-sea Baranof fan sediment.

In order to conceptually visualize the position of the Pacific plate along the margin through time, a simplified plate reconstruction was also built in order to provide insight into where the now-downwarped Pacific plate was located along the margin during its 13 my existence (age data from Müller et al., 1997). We used GPlates software (see Data and Resources) for the reconstruction, which is based on a tectonic model by Seton et al. (2012); however, we supplement interpretation of the reconstruction with more detailed information of the margin from recent studies (e.g., Doubrovine and Tarduno, 2008; DeMets et al., 2010; Elliott et al., 2010; Tréhu et al., 2015) that provide more local insight than the plate reconstruction on its own. We assume that the plate boundary remained fixed in time and space relative to North America. We also assume that the clockwise change of the local Pacific plate motion vector occurred at $6 \mathrm{Ma}$, consistent with data from Doubrovine and Tarduno (2008) and that convergence rates and plate motion vectors remained constant since that time.

\section{Observations}

Faults

The QCF has been mapped in the past using GLORIA backscatter data and 2D seismic reflection profiles (von Huene et al., 1979; Carlson et al., 1985, 1988; Scheidhauer, 1997; Rohr et al., 2000). A new interpretation of the segment from $\sim 53^{\circ}-56^{\circ} \mathrm{N}$, based on the EW9412 data, is discussed by Tréhu et al. (2015). Our updated maps (Fig. 3), generated using similar methods, were compared with a comprehensive fault database compiled by the Geological Society of America (Reed et al., 2005; Fig. 3). New mapping confirms the traces of major faults and splays along the QCF system as identified by the database, giving us confidence in the accuracy of the QCF's seafloor geometry.

Offshore Haida Gwaii, the QCF can be imaged within the slope sediment, which is commonly referred to as the QCT (e.g., Hyndman and Hamilton, 1993). The shallow manifestations of the QCF in this region change along strike and have been discussed in several studies (e.g., Rohr et al., 2000; Tréhu et al., 2015). The QCT is composed of sediment and likely some crystalline rock as well; a refraction study by Dehler and Clowes (1988) detected ocean crustal velocities 4-5 km beneath the seafloor of the outer QCT. The morphology of the QCT is variable along strike, with the main trace of the QCF sometimes marked by half-grabens and other times by a narrow ridge (Rohr et al., 2000). Recent mapping on the QCF south of $53^{\circ} \mathrm{N}$ also indicates small pull-apart basins along strike (Barrie et al., 2013).

In the subsurface, the QCF is observable most often as a vertical discontinuity with small displacement on the seafloor and near-seafloor reflections (e.g., Fig. 4). Available seismic data often confirm the location of the QCF and assist in identifying splay faults, and we map the QCF confidently in the top $\sim 1 \mathrm{~s}$ TWTT $(\sim 750 \mathrm{~m})$ of sediment. Because of somewhat chaotic reflectivity and seafloor multiples, however, we cannot interpret the fault below a depth of $\sim 750 \mathrm{~m}$ beneath the seafloor.

The strike of the QCF has several discrete changes; notably, a bend in the fault at $53.2^{\circ} \mathrm{N}$ marks a change in fault strike from $\sim 328^{\circ}$ (clockwise from north) south of $53.2^{\circ} \mathrm{N}$ near Haida Gwaii to a strike of $\sim 338^{\circ}$ north of the Dixon Entrance (e.g., Rohr et al., 2000; Tréhu et al., 2015). This bend causes the angle of convergence with the Pacific plate to change from $>15^{\circ}$ near Haida Gwaii to $\sim 5^{\circ}$ north of $53.2^{\circ} \mathrm{N}$ (Tréhu et al., 2015).

The QCF is the dominant structural feature within the slope sediment. Farther offshore, however, there is a notable series of buried normal faults (e.g., Fig. 5), with a higher density of these faults seaward of the Dixon Entrance at $54^{\circ} \mathrm{N}$. We observe a decrease of normal faults to the north and where seamounts are present at $\sim 53^{\circ} \mathrm{N}$. Dips on the faults are between $60^{\circ}$ and $70^{\circ}$ on average, with many extending as deep as the top of Pacific basement, but none reaching the seafloor. Normal faults are buried beneath an onlap surface (SEAK2) within the basin sediment, under 200-1000 m of sediment. The package of sediment above the normal faults thickens toward the coastline.

\section{Pacific Basement}

The top of the igneous Pacific basement surface was mapped along seismic reflection profiles adjacent to and 


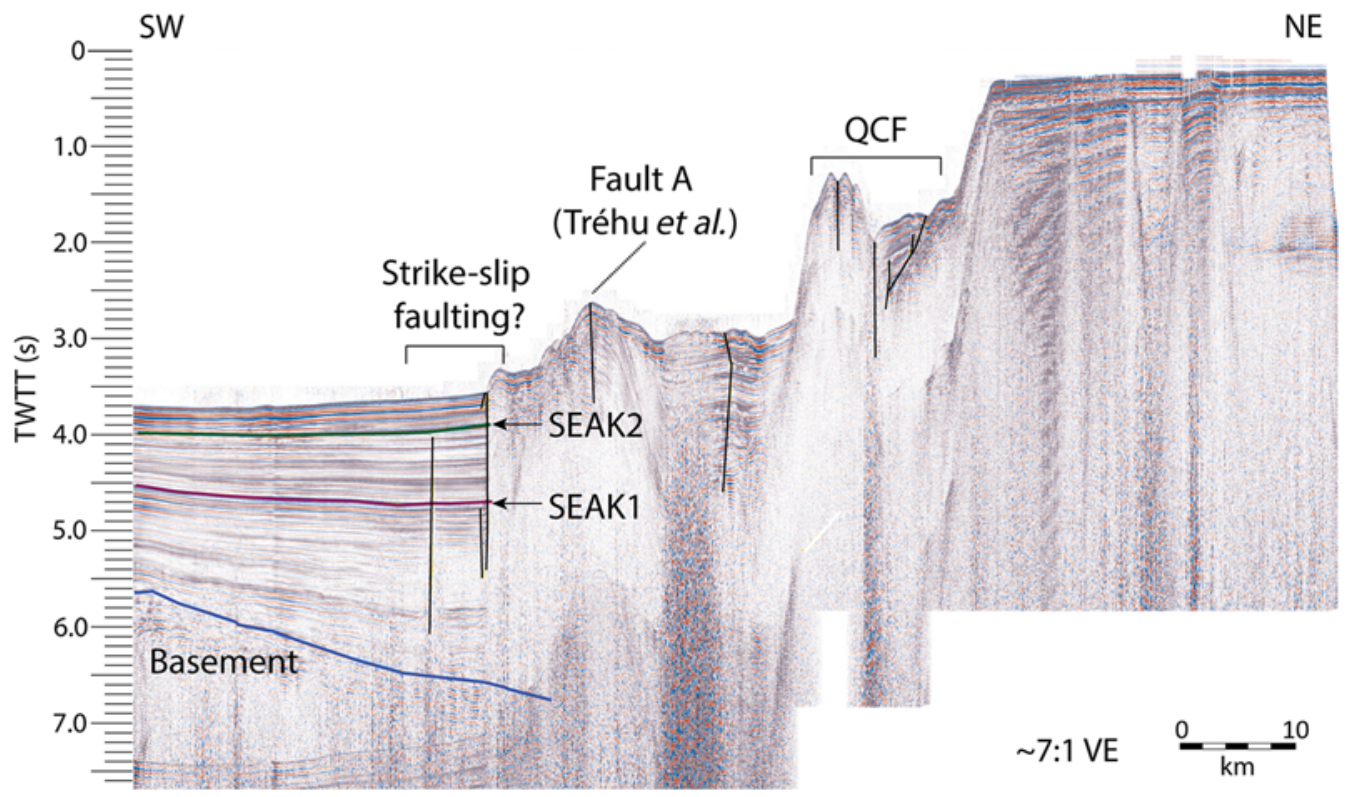

Figure 4. USGS seismic reflection profile L-3-78-EG_951 (line location shown on Fig. 2); the northernmost of the lines is shown in this study. The vertical axis shows depth in two-way travel time (TWTT). Basement, SEAK1, and SEAK2 horizons are plotted as thick lines along with strike-slip faulting and a fault from Tréhu et al. (2015; thinner subvertical lines). The top of the igneous oceanic basement here is dipping toward North America at $\sim 1.5^{\circ}$ in the profile, with near-vertical strike-slip faulting evident in the sediment atop the plate. Seismic lines here and in Figures 5-7 are plotted on the same scale to give a sense of relative change along strike. The color version of this figure is available only in the electronic edition.

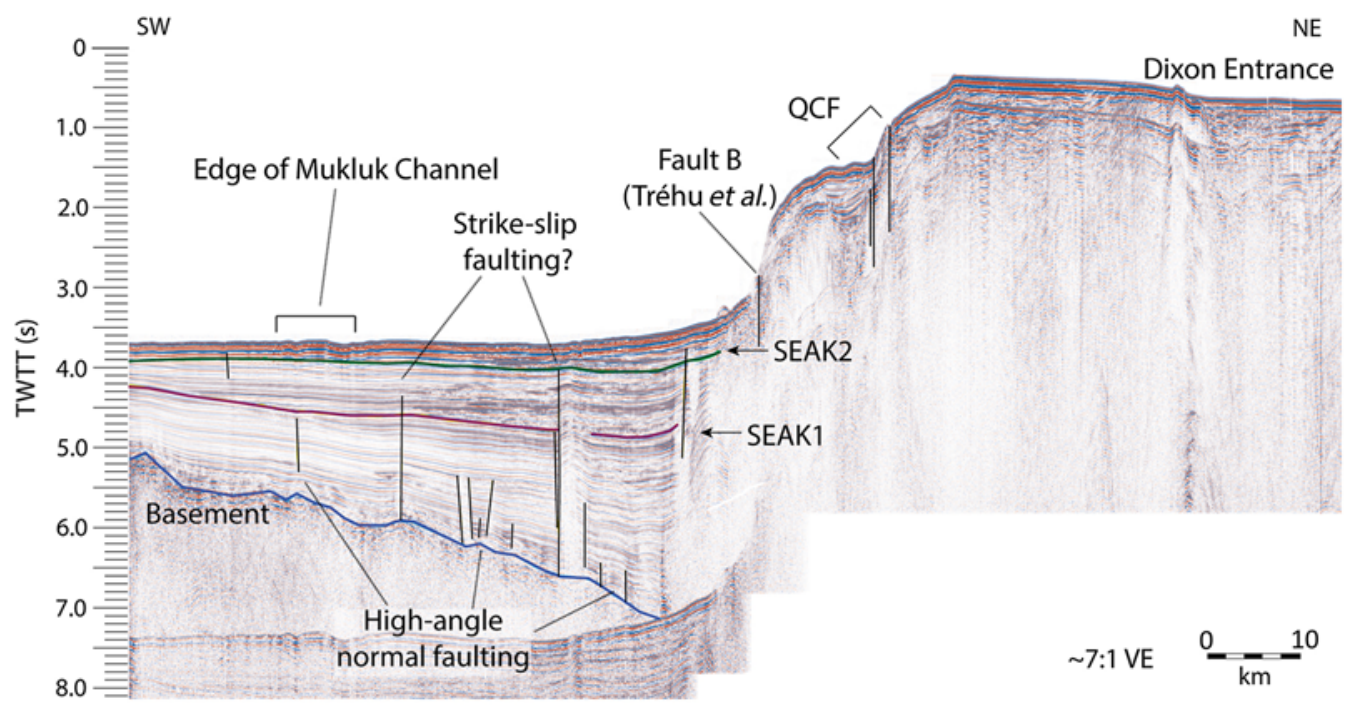

Figure 5. USGS seismic reflection profile L-5-77-EG_03 (line location shown in Fig. 2). The vertical axis shows depth in TWTT. Basement, SEAK1, and SEAK2 horizons are plotted as thick lines along with strike-slip faulting, normal faulting, and a fault from Tréhu et al. (2015; thinner subvertical lines). The oceanic basement is dipping more steeply here than in Figure 4, with some normal faulting in the sediment atop the plate. On the seafloor and uppermost subsurface, the influence of the Mukluk Channel is visible as slightly disturbed, highamplitude reflections. The color version of this figure is available only in the electronic edition.

seaward of the QCF. The basement surface was only mappable beneath the deep seafloor, as high reflectivity in the slope sediment prevents imaging below $\sim 1 \mathrm{~km}$ depth. Interpolation and extrapolation of basement picks up to $\sim 50 \mathrm{~km}$ between and at the edges of seismic data transects offshore allow for visualization on a regional scale. Note that no picks were made beneath the slope sediment of the QCT.
Moving from north to south, the dip of the Pacific basement adjacent to the QCF changes significantly along strike (see Fig. 2 for line crossing locations). North of $55^{\circ} \mathrm{N}$, the basement does not have a significant dip, but line L-3-78EG_951 crossing the QCF perpendicularly at $55^{\circ} \mathrm{N}$ shows the Pacific basement dipping toward North America at an angle of $\sim 1.5^{\circ}$ (Fig. 4). Landward dip increases southward 


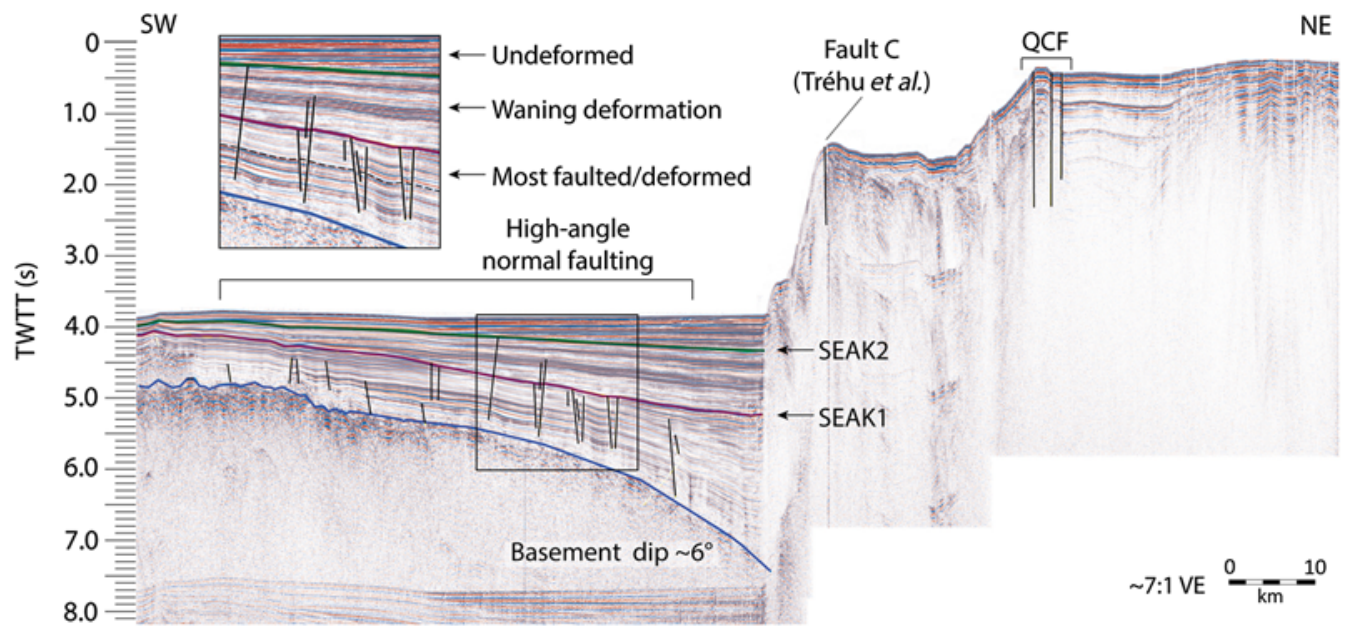

Figure 6. USGS seismic reflection profile L-5-77-EG_02 (line location shown in Fig. 2); the line closest to a $54^{\circ} \mathrm{N}$ crossing of the QCF is where we observe maximum flexure. The vertical axis shows depth in TWTT. Basement, SEAK1, and SEAK2 horizons are plotted as thick lines along with strike-slip faulting, normal faulting, and a fault from Tréhu et al. (2015; thinner subvertical lines). The top of the Pacific crust dips toward North America at about $6^{\circ}$, with high-density normal faulting in the sediment above the plate. The inset shows a closer view of the normal faulting and sedimentary relationships with interpretations. The dashed line in the inset indicates the onset of growth strata and therefore syntectonic sedimentary deposition. The color version of this figure is available only in the electronic edition.

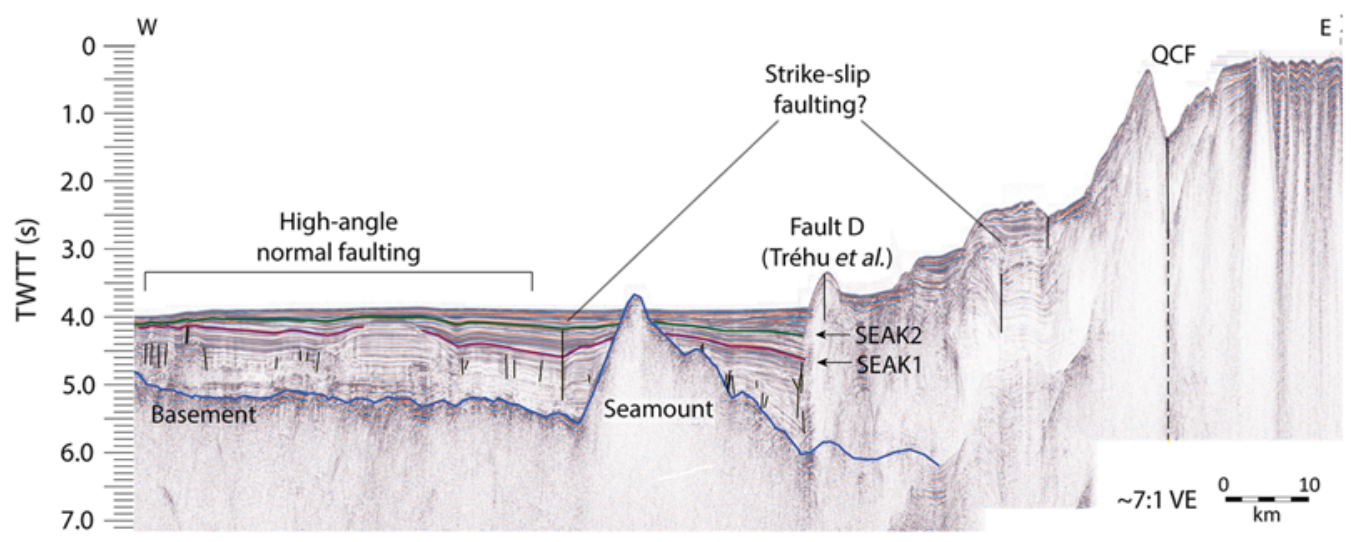

Figure 7. USGS seismic reflection profile L-5-77-EG_01 (line location shown in Fig. 2); the southernmost margin-orthogonal line is included in this study. The vertical axis shows depth in TWTT. Basement, SEAK1, and SEAK2 horizons are plotted as thick lines along with strike-slip faulting, normal faulting, and a fault from Tréhu et al. (2015; thinner subvertical lines). The top of the Pacific crust here is significantly shallower than lines located to the north of it, with a seamount visible in the subsurface as well. The color version of this figure is available only in the electronic edition.

(see line L-5-77-EG_03, Fig. 5), finally reaching an observed maximum dip of $\sim 6^{\circ}$, with basement reaching an observed maximum depth of $\sim 7.5 \mathrm{~s}$ TWTT $(\sim 8 \mathrm{~km}$ below sea level and $\sim 5 \mathrm{~km}$ below seafloor), as shown on line L-5-77EG_02 (Fig. 6).

South of $54^{\circ}$, at which the strike of the QCF changes from $338^{\circ}$ to $328^{\circ}$, the Pacific basement shallows dramatically and the dip toward the continent seems to decrease, as illustrated by seismic reflection profile L-5-77-EG_01 (Fig. 7). We also observe a nearly completely buried seamount in this area. South of the seamounts, the Pacific plate basement deepens along central Haida Gwaii. This is constrained by only one seismic line (Fig. 8), but other studies have inferred crustal flexure here by looking at the bathym- etry of the Queen Charlotte Trough (e.g., Chase and Tiffin, 1972), low-penetration seismic data (Davis and Seemann, 1981), and negative gravity anomalies (Rohr, 2015). South of this crustal deepening near Haida Gwaii, the basement shallows southward toward the Tuzo Wilson seamounts $\sim 51.5^{\circ} \mathrm{N}$ (see transect F-7-89-EG_58, Fig. 8), where new ocean crust is exposed at the seafloor (Carbotte et al., 1989; Rohr and Furlong, 1995). A $1 \mathrm{~km}$ resolution grid of basement picks (Fig. 9) illustrates the changing structure of the Pacific plate along the QCF.

A plate tectonic reconstruction based on Seton et al. (2012) shows that downwarped crust at the QCF between $53.2^{\circ}$ and $56^{\circ} \mathrm{N}$ was generated at the Juan de Fuca Ridge. The youngest (and most downwarped) of this crust, now forming a 


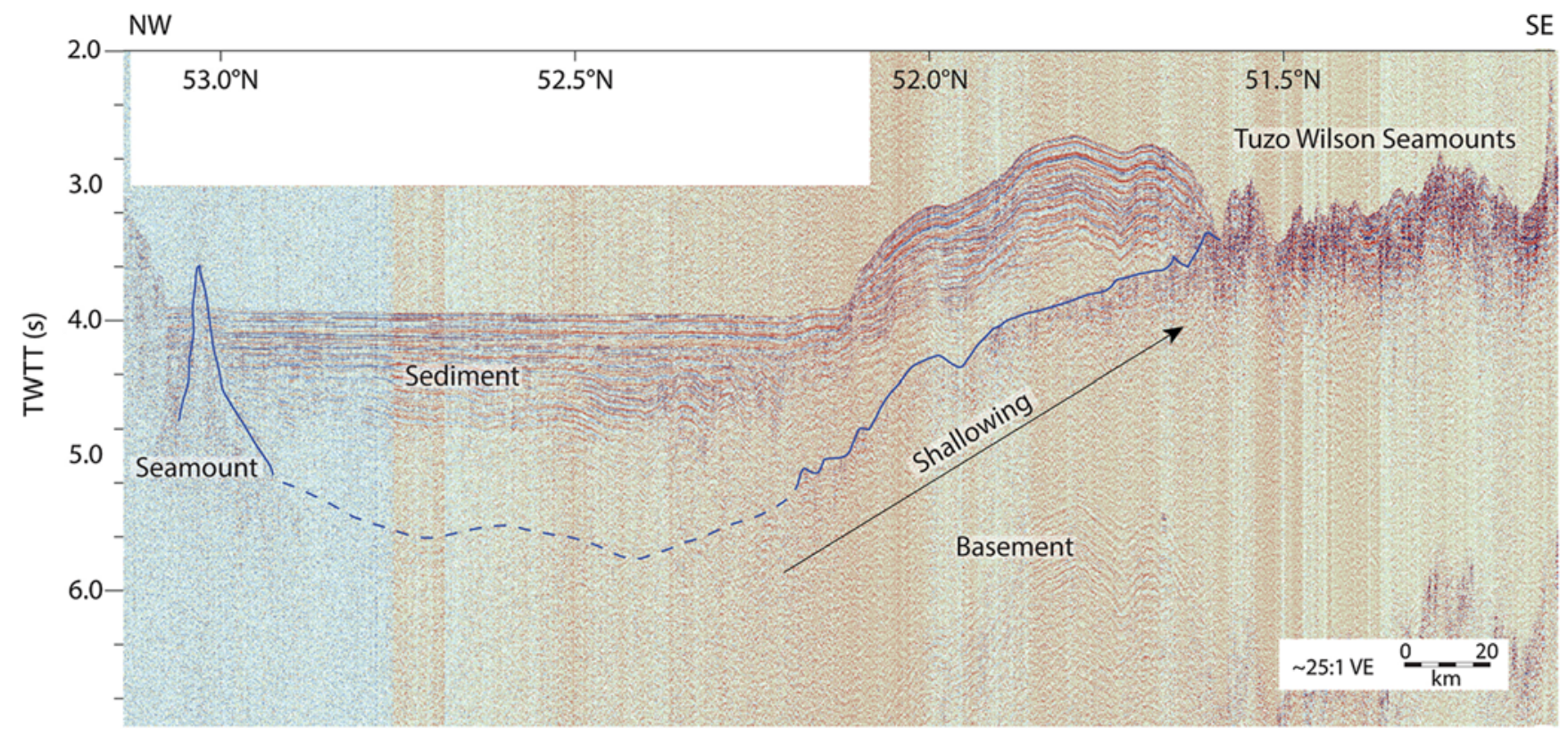

Figure 8. USGS seismic reflection profile F-7-89-EG_58 (line location shown on Fig. 2), with a QCF strike-parallel line showing the basement crust shallowing southward to the Tuzo Wilson seamounts, where there is active volcanism and basaltic crust exposed at the seafloor. The basement horizon here is plotted as a thick line and is indicated with a dashed line where location is uncertain. The vertical axis shows depth in TWTT. Note that this seismic line is plotted on a different scale than the seismic data shown in Figures 4-7 in order to show a larger region. The color version of this figure is available only in the electronic edition.

flexural depression at $54^{\circ} \mathrm{N}$ (near seismic line L-5-77-EG_02; see Fig. 6), was generated at the ridge $\sim 13 \mathrm{Ma}$. After creation, this crust moved northward along the QCF until the $\sim 15^{\circ}$ clockwise rotation in Pacific plate motion at $6 \mathrm{Ma}$ (from Doubrovine and Tarduno, 2008). At $6 \mathrm{Ma}$, this crust was located $\sim 250 \mathrm{~km}$ south of its current position assuming a $4.4 \mathrm{~cm} / \mathrm{yr}$ rate of relative motion (Elliot et al., 2010), exposed to the higher convergence rates along the QCF south of $\sim 53^{\circ} \mathrm{N}$ (which we assume to have been consistent since $6 \mathrm{Ma}$ ). At $4 \mathrm{Ma}$, the Explorer plate was generated south of the QCF (Botros and Johnson, 1988). Younger oceanic crust adjacent to the QCF would have continued to experience compression associated with oblique convergence south of the bend. Convergence and any associated downwarping would have continued until the crust translated north past the bend, and by $2 \mathrm{Ma}$, the now-flexed part of the Pacific plate would have moved almost entirely past the zone of oblique convergence into a dominantly strike-slip regime.

\section{Gravity and Magnetics}

Interpreted magnetic anomalies (Fig. 10) define a Pacific plate that decreases in age to the south, from 20 my at the Yakutat block to 0 my at the Explorer triple junction. The Aja fracture zone intersects the QCF at $56^{\circ} \mathrm{N}$, which is coincident with the northern extent of the observed Pacific crustal flexure.

Gravity data (Fig. 3) exhibit local highs where seamounts are present and lows at the thick sedimentary deposits of the Queen Charlotte Trough and terrace. South of $56^{\circ} \mathrm{N}$, areas immediately adjacent to the QCF are characterized by negative gravity anomalies. These gravity lows vanish at the southernmost QCF near the Explorer triple junction, where basement rock is very young, shallow, and not yet covered with sediment (Rohr, 2015).

\section{Historic Earthquake Ruptures}

The relationship between our structural analysis and earthquake events is shown in Figures 9 and 10. Apart from the segments that ruptured in the 2012 Haida Gwaii and 2013 Craig events, nearly the entire QCF ruptured between the northern $M_{\mathrm{s}} 7.6$ event in 1972 and the southern $M_{\mathrm{s}} 8.1$ event in 1949 (Fig. 1). The northern edge of the aftershock zone of the 5 January 2013 Craig event, at $56^{\circ} \mathrm{N}$, correlates well with the boundary between the 1972 and 1949 event rupture zones. Aftershocks of the Craig strike-slip event overlap with the northernmost $\sim 125 \mathrm{~km}$ of the rupture zone of the 1949 event (Plafker et al., 1994; Fig. 1), assuming the longer rupture model estimated from the 1949 aftershocks (Rogers, 1986). The northern extent of the Craig event's rupture zone is also adjacent to downwarped oceanic crust (Fig. 9) and thick sediment deposits indicated by negative gravity anomalies (Fig. 3), all of which appear to extend only to $\sim 56^{\circ} \mathrm{N}$.

The epicenter of the 28 October 2012 Haida Gwaii thrust event overlaps with the southern end of the 1949 strike-slip event's rupture zone (Fig. 1), although there are several rupture models for the 1949 event that disagree about the geographic extent of the rupture (Bostwick, 1984; Rogers, 1986; Ding et al., 2015). Despite the extent of the 1949 


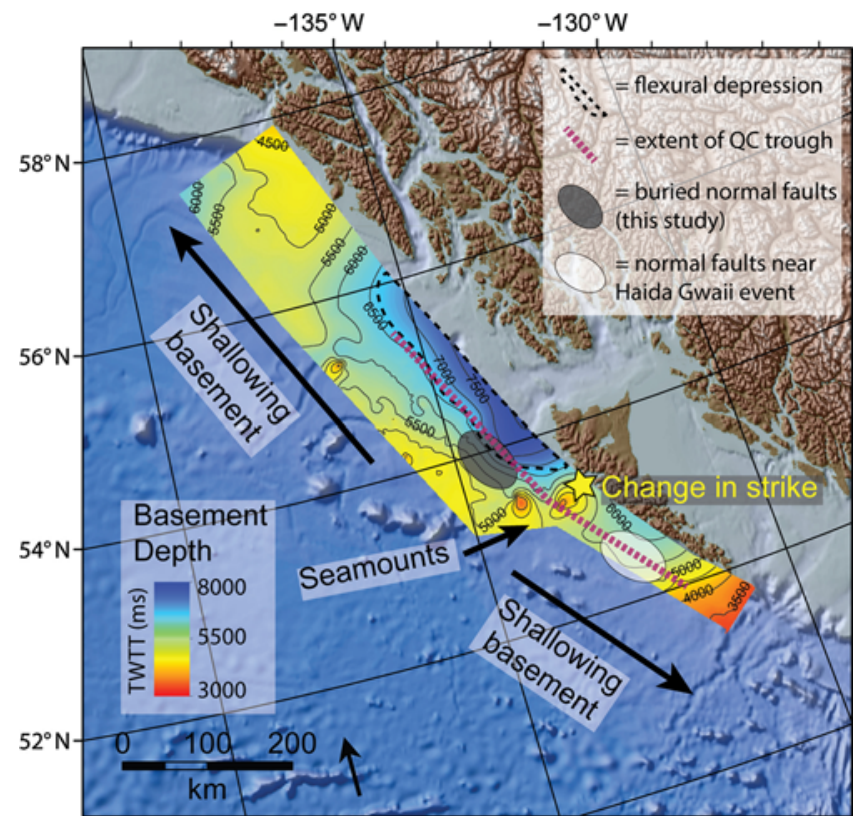

Figure 9. Gridded structure contour map showing depth to the top of the igneous basement crust. Grid is in TWTT depth with a contour interval of $500 \mathrm{~ms}$. Picks are interpolated and extrapolated over distances as much as $\sim 50 \mathrm{~km}$ from seismic reflection lines (Fig. 2). There are no picks beneath the Queen Charlotte terrace. The area with the highest-density normal faults as mapped in this study is highlighted by a gray ellipse. The approximate area of Haida Gwaii normal fault aftershocks (derived from the Global Centroid Moment Tensor catalog; Ekström et al., 2012; see also Farahbod and Kao, 2015, and Kao et al., 2015) is denoted by a white ellipse. The extent of the Queen Charlotte (QC) Trough at the seafloor is also plotted by a thick dashed line. Interpretations indicate shallowing crust outward of apparent maximum flexure located at $54^{\circ} \mathrm{N}$. The area of the figure covers the same region as Figure 2. The color version of this figure is available only in the electronic edition.

aftershocks (Plafker et al., 1994; Fig. 1), a seismic gap in the Haida Gwaii region was predicted (Rogers, 1986; Bérubé et al., 1989). The entirety of the Haida Gwaii aftershock zone is just south of $53.2^{\circ} \mathrm{N}$, where the strike of the QCF changes from $328^{\circ}$ to $338^{\circ}$ (Farahbod and Kao, 2015; Kao et al., 2015). Aftershocks of the Haida Gwaii event are primarily within the Pacific plate, and the majority of the aftershocks have normal fault mechanisms (Lay et al., 2013; Kao et al., 2015).

\section{Interpretation and Discussion}

The primary new observations made in this study are (1) the change in flexure of the Pacific plate along strike on the QCF and (2) the distribution of normal faults in sediment overlying the Pacific crust offshore. We observe plate flexure along the central QCF between $53.2^{\circ}$ and $56^{\circ} \mathrm{N}$, with observed maximum downwarping at $54^{\circ} \mathrm{N}$. This region is adjacent to a segment of the QCF characterized by strike-slip faulting, north of where oblique convergence occurs at rates reaching $\sim 20 \mathrm{~mm} / \mathrm{yr}$. We observe normal faulting in the



Figure 10. Bathymetry image overlaid by positive magnetic anomalies and the modern coastline. The Aja fracture zone, Kodiak-Bowie seamounts, simplified regional fault traces, and select ages of anomalies near the margin are shown on the map. Aftershocks of the Craig and Haida Gwaii earthquakes (northern and southern clusters of circles, respectively) are included for context (derived from the Global Centroid Moment Tensor catalog; Ekström et al., 2012). Two possible fault segment boundaries, one at $53.2^{\circ} \mathrm{N}$ and the other at $56^{\circ} \mathrm{N}$, are denoted by stars. The area of the figure covers the same region as Figure 2. The color version of this figure is available only in the electronic edition.

sediment above the Pacific plate within and seaward of the downwarped region, with the highest density of normal faults in the sediments observed where downwarping reaches a maximum. We incorporate these primary results into a model for how the Pacific plate has evolved throughout the past $6 \mathrm{my}$ that has relevance for understanding of modern mechanisms of convergence being accommodated along the southern QCF in the location of the Haida Gwaii earthquake.

\section{Faulting}

The main trace of the QCF changes strike at $53.2^{\circ} \mathrm{N}$ (Fig. 3), based on observations of GLORIA backscatter. South of $53.2^{\circ} \mathrm{N}$ near central Haida Gwaii, the fault strikes at $328^{\circ}$ and is characterized by transpression (Rohr et al., 2000; Tréhu et al., 2015). North of $53.2^{\circ}$, the QCF strikes $338^{\circ}$ and is characterized by strike-slip faulting (Ristau et al., 2007) with far lower amounts of transpression (Tréhu et al., 2015). In addition to major splays such as the Chatham Strait fault, the northern region also shows a number of minor splays within the QCT (Fig. 3). Tréhu et al. (2015) discuss reactivated faults in this northern region. Although the QCF is thought to have existed as a transform boundary for the last 40-50 my (e.g., Atwater, 1970; Crouch et al., 1984; Haeussler et al., 2003), the rotation in Pacific plate motion 
at $6 \mathrm{Ma}$ (Doubrovine and Tarduno, 2008) leading to $15-20 \mathrm{~mm} / \mathrm{yr}$ vector of convergence along Haida Gwaii may have caused complexities in the fault. It is possible that splays in the northern QCF are very young, developing after this plate motion change at $6 \mathrm{Ma}$, as discussed by Tréhu et al. (2015). Tréhu et al. further suggest that the angle of convergence is a key factor controlling the response of the upper crust to transpression. South of the $53.2^{\circ} \mathrm{N}$ bend near Haida Gwaii, a convergence angle of $>15^{\circ}$ leads to accommodation of compression via a thickening of the upper crust and sediments (Mackie et al., 1989; Rohr et al., 2000) through thrust and reverse faulting and folding parallel to the QCF (pure shear). In Tréhu et al.'s model, the decrease in the amount of convergence north of $53.2^{\circ} \mathrm{N}$ leads to deformation via splay faults oblique to the main fault (simple shear). They ultimately conclude that faults formed by thrusting south of $53.2^{\circ} \mathrm{N}$ are oriented at an angle favorable for accommodation of compression via simple shear, and that deformation is focused on those structures which are reactivated as wrench faults as the Pacific plate moves around the bend in the QCF.

We confirm the presence of the QCF main trace, its splays, and the vertical fault plane suggesting strike-slip motion using available seismic reflection data along the entirety of its strike. The structure and dip of the QCF at depth, however, remain uncertain. For instance, we map a vertical QCF $\sim 1 \mathrm{~km}$ beneath the seafloor near the rupture of the 2013 Craig earthquake, though the earthquake ruptured a fault plane dipping at $63^{\circ}$, with a hypocenter at $10 \mathrm{~km}$ depth (USGS, see Data and Resources). The deep structure of the QCF and the plate interface is a particularly interesting question near the epicenter of the Haida Gwaii thrust earthquake of 2013. We infer a gently dipping Pacific plate in the region of the Haida Gwaii event. The Haida Gwaii earthquake fits in well with this observation, as the mainshock ruptured a fault dipping $18.5^{\circ}$ to the east at $14 \mathrm{~km}$ depth beneath the seafloor of the QCT (James et al., 2013; Lay et al., 2013; USGS, see Data and Resources). In addition, several recent studies based on seismicity, GPS observations of coseismic and postseismic motion, and thermal modeling (Farahbod and Kao, 2015; Kao et al., 2015; Nykolaishen et al., 2015; Wang et al., 2015) support the Haida Gwaii event as a shallow megathrust on the Pacific-North American plate interface near the QCF.

We suggest there are two potential fault segment boundaries along the QCF. At $56^{\circ} \mathrm{N}$, the boundary between the 1972 and 1949 rupture areas coincides with the intersection of the Aja fracture zone and the QCF (Fig. 10), which also marks an $\sim 3$ my offset in Pacific plate age. In addition, gridded Pacific basement travel-time picks indicate that flexure of the plate exists only south of $56^{\circ} \mathrm{N}$, and gravity data indicate thicker sediment deposits there as well (Fig. 3). These structural differences across $56^{\circ} \mathrm{N}$ provide a lithospheric discontinuity that may impede earthquake rupture propagation (e.g., Wesnousky, 2006) and could explain the $56^{\circ} \mathrm{N}$ limit of the 2013 Craig event's aftershock zone.
The other possible fault segment boundary is located south near $53.2^{\circ} \mathrm{N}$, at the bend in the QCF and where possible members of the Kodiak-Bowie seamounts are present (Fig. 10). Either or both may limit the extent of rupture during some earthquakes. Our observations also show that the Pacific plate flexes downward sharply north of $53.2^{\circ} \mathrm{N}$. Because of the change in strike of the QCF here, $53.2^{\circ} \mathrm{N}$ represents an abrupt transition in structural regimes along the QCF (Tréhu et al., 2015). Research has shown that fault steps and underthrust seamounts can limit rupture propagation via stress changes across them (King and Nábělek, 1985; Wesnousky, 2006; Wang and Bilek, 2011). Disturbed magnetic anomalies here correlate with and are likely related to the seamounts, though we cannot determine if any have been underthrust. The $M_{\mathrm{s}} 8.1$ event of 1949 may have extended across this boundary according to some models, although surface-wave directivity suggests a rupture propagating northward of the $53.5^{\circ} \mathrm{N}$ epicenter (Bostwick, 1984; Rogers, 1986), leading to a possible seismic gap to the south. The 2012 Haida Gwaii rupture is located entirely south of the structural transition across $53.2^{\circ} \mathrm{N}$, though given its thrust mechanism, it does not seem to have ruptured the QCF proper. It is possible that the QCF here has yet to rupture in a large event, or that it is has been accommodating strike-slip motion aseismically over time (Lay et al., 2013). We recognize that interpretations of segmentation are based on very few direct observations, and additional data and/or numerical modeling are needed to test whether these boundaries do indeed limit the extent of ruptures.

Aside from the changing structures along strike of the QCF, sedimentary deformation and unconformities offshore of the QCF provide insight into the timing of observed flexural deformation and support interpretations of the origin of the observed flexure (see the Crustal Flexure section for discussion). We observe normal faulting in the sediment just above the Pacific plate where flexure occurs in the underlying crust (e.g., Fig. 6), suggesting that normal faulting is related to plate flexure here. We map three distinct sedimentary packages atop the Pacific plate, separated by two onlap unconformities (SEAK1 and SEAK2). Normal faults appear exclusively in the lower two sediment packages and at a higher density where downwarping is greater (Fig. 6, inset). The lowermost package (basement-SEAK1) is the most deformed, with tilted layers, extensive normal faulting, and some growth strata in the upper part of the package and toward the shelf (Fig. 6, inset). These observations suggest faulting coincident with plate bending and later phases of syntectonic deposition. The middle package (SEAK1SEAK2) exhibits gently dipping strata with a few normal faults extending into it, suggesting waning deformation during the deposition of these strata. The most recent sedimentation (SEAK2-seafloor) appears as high-amplitude, flatlying, and undeformed layers (Fig. 6, inset), suggesting that extensional deformation is no longer active today. Without deep cores in the area, it is impossible to date mapped surfaces and faults, though other studies have interpreted the 
SEAK1 horizon as a Miocene-Pliocene unconformity, identifiable by truncating reflectors and a change in interval velocity (Snavely et al., 1981; Scheidhauer, 1997; Tréhu et al., 2015).

\section{Crustal Flexure}

The top of the igneous basement of the Pacific plate dips landward toward the North American plate between 53.2 and $\sim 56^{\circ} \mathrm{N}$ (Fig. 9), reaching an observed maximum dip of $\sim 6^{\circ}$ at $\sim 54^{\circ} \mathrm{N}$ (Fig. 6). The plate boundary here, however, does not exhibit any major thrust faults and has only ruptured in strike-slip earthquakes in recorded history. These observations and examination of plate reconstruction suggest that the crust characterized by flexure between $54^{\circ}$ and $56^{\circ} \mathrm{N}$ was undergoing oblique convergence for $0-4$ my (between $\sim 6$ and $\sim 2 \mathrm{Ma}$ ), before being translated north of the fault bend at $53.2^{\circ} \mathrm{N}$. The Pacific plate currently near $53.2^{\circ} \mathrm{N}$ would have been exposed to convergence for a longer period of time prior to translating past the obliquely convergent southern QCF, whereas lithosphere now located at $56^{\circ} \mathrm{N}$ would have passed the bend into a strike-slip regime more quickly and would have been exposed to convergence for less time. The plate reconstruction is consistent with observations of changing flexure along strike.

Analogous flexure may be occurring currently along the southern QCF (where the Haida Gwaii event occurred). A shallower crustal deepening here reaches $\sim 5.5 \mathrm{~s}$ TWTT ( $\sim 6 \mathrm{~km}$ depth), approximately $2 \mathrm{~km}$ shallower than the flexure we observe at $54^{\circ} \mathrm{N}$ (Fig. 8), and others have supported a dipping plate here using a variety of geophysical data (e.g., Chase and Tiffin, 1972; Davis and Seemann, 1981; Prims et al., 1997; Nykolaishen et al., 2015; Wang et al., 2015). Flexure between $54^{\circ}$ and $56^{\circ} \mathrm{N}$ appears to be inactive based on observations of recent undisturbed sediment but seems active south of $53.2^{\circ} \mathrm{N}$ because of normal faulting in the Pacific plate after the Haida Gwaii earthquake of 2012 (Lay et al., 2013). The aftershocks imply plate-bending faults from downwarping (Kao et al., 2015), a common phenomenon observed at subduction zones (Masson, 1991). We interpret the buried normal faults in the sediment above the downwarped plate at $54^{\circ} \mathrm{N}$ to be the signature of similar events in the past when the plate was farther south.

To explain our observations, we support a Pacific plate underthrusting model with flexure initiated by underthrusting and subsequently preserved by sediment loading in the trough and QCT. Figure 11 of this study and figure 2 of Tréhu et al. (2015) show that the implied amount of underthrusting decreases gradually north- and southward of $53.2^{\circ} \mathrm{N}$. An underthrusting model would explain the observed maximum in apparent flexural depression of the Pacific plate near $54^{\circ} \mathrm{N}$, which is the segment of plate that has been exposed to pronounced convergence along the southern QCF for the longest period of time, as well as a northward-decreasing amount of flexure (Fig. 11). Some of the $\sim 100-120 \mathrm{~km}$ of total predicted convergence since 6 Ma has undoubtedly

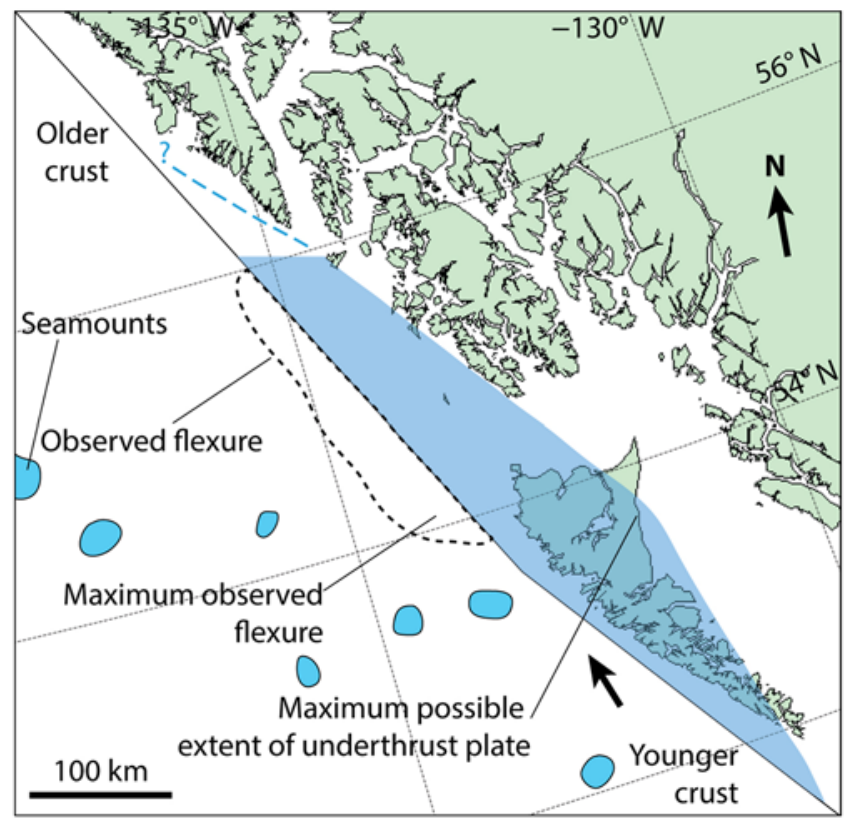

Figure 11. Schematic diagram of the maximum possible cumulative tectonic overlap (shaded region) between the Pacific and North American plates due to convergence along the QCF from $6 \mathrm{Ma}$ to present. The overlap presented here assumes pure underthrusting and does not show the effects of intraplate deformation or thickening, which could be significant; this figure does not represent our final model for convergence accommodation (see Fig. 12). The overlap was calculated based on modern MORVEL plate motion vectors (DeMets et al., 2010) and assumes a simplified QCF geometry that remains fixed to North America, a $20^{\circ}$ angle of convergence with the Pacific plate motion vector south of $53.2^{\circ} \mathrm{N}$, a $5^{\circ}$ angle of convergence north of $53.2^{\circ} \mathrm{N}$, and a $2 \mathrm{D}$ plane of plate motion. The mapped region of flexure is shown as a dashed line to illuminate the relationship between convergence and flexure. The color version of this figure is available only in the electronic edition.

been accommodated within the plates, though the ongoing question of how much is beyond the scope of this study.

The tectonic history of the margin is consistent with our interpretation; Figure 12 illustrates a conceptual model. The minimum age of the Pacific plate at $54^{\circ} \mathrm{N}$, where we observe apparent maximum flexure, is $\sim 13$ my. If we assume that flexure did indeed initiate with the onset of QCF convergence at $\sim 6 \mathrm{Ma}$ due to a combination of underthrusting and sediment loading as accommodation space was created, then we can say that the deformed sediment in the lowermost package (basement-SEAK1) was faulted concurrently with flexure (Fig. 12). We observe growth strata in the upper part of this package, which supports a syntectonic deposition of some later strata (Fig. 6, inset). Thus, we interpret that much of the lowermost package was deposited between 13 and $6 \mathrm{Ma}$, with deformation and growth strata initiating sometime after $6 \mathrm{Ma}$. This interpretation is consistent with that of Snavely et al. (1981), stating that the SEAK1 unconformity represents the Miocene-Pliocene unconformity ( 5.3 Ma).

After $6 \mathrm{Ma}$, convergence and strike-slip motion both continued until the flexed portion of the plate bypassed the more-convergent southern QCF by $\sim 2 \mathrm{Ma}$, suggesting 

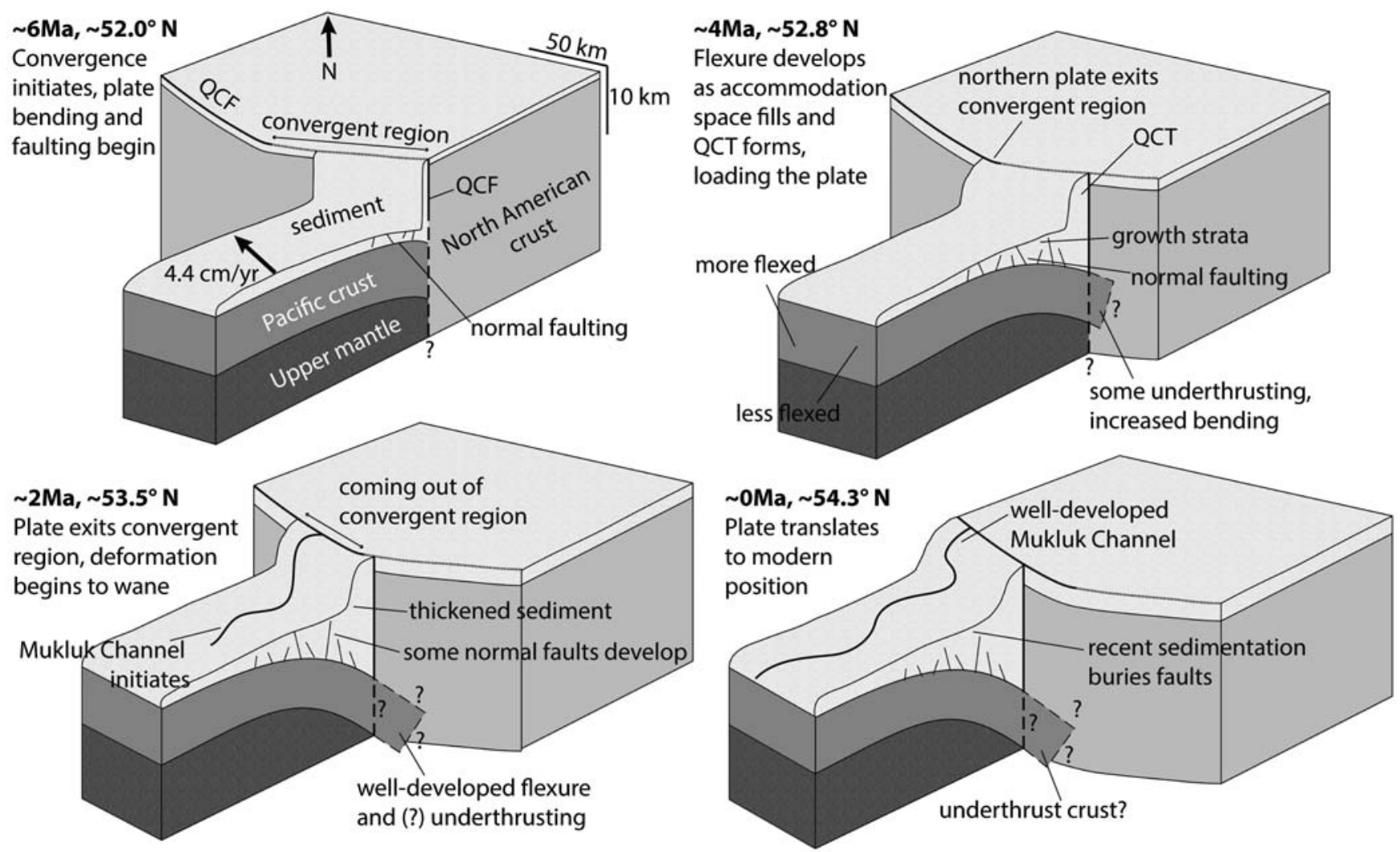

Figure 12. Development of the flexure and underthrusting of a piece of the Pacific plate through time, starting at 6 Ma when convergence initiated along the southern QCF, are shown. Snapshots in time of the flexure and fault development until the plate translates to its modern position at $\sim 54.3^{\circ} \mathrm{N}$ are shown.

a period of diminishing deformation sometime between 6 and 2 Ma. The middle sedimentary package (SEAK1SEAK2) is the least constrained in time, but smaller amounts of deformation via faulting and tilting support a waning deformation interpretation (Fig. 12). The SEAK1-SEAK2 package, then, must have been deposited and deformed beginning sometime after $6 \mathrm{Ma}$ and ending at $\sim 2 \mathrm{Ma}$. The relatively large thickness of this middle package could also indicate higher sedimentation rates during this period, some of which is perhaps related to the onset of northern hemisphere glaciation (Raymo, 1994). This timeline is consistent with interpretation of the onset of deposition in the Baranof deep-sea fan system, which is thought to have undergone more rapid deposition beginning at $\sim 7 \mathrm{Ma}$ and further intensification during the Pleistocene (Walton et al., 2014).

The uppermost sedimentary package (SEAK2-seafloor) is the least deformed and is marked by an increase in acoustic amplitude. Given the interpretation of the timing of the other sedimentary packages, the uppermost package was most likely deposited after $2 \mathrm{Ma}$ (Fig. 12). We were able to match this package with deposits from the nearby Mukluk sea channel, which likely initiated sometime around the onset of northern hemisphere Pleistocene glaciation at $\sim 2.58 \mathrm{Ma}$ (Walton et al., 2014). The age of the Mukluk Channel is consistent with the interpretation of an upper sedimentary package age of $\sim 2$ my.
Although continued underthrusting north of $53.2^{\circ} \mathrm{N}$ is not thought to be occurring, despite a small $\left(\sim 5^{\circ}\right)$ angle of oblique convergence (e.g., Tréhu et al., 2015), flexure of the Pacific plate has been preserved after it translated into a strike-slip regime. This preservation of downwarping may be a combination of sediment loading and a portion of the Pacific plate remaining pinned beneath North America, a remnant of past underthrusting. Our model assumes that flexure initiated at $\sim 6 \mathrm{Ma}$, at which time convergence along the southern QCF would have led to underthrusting and downwarping, resulting in creation of sedimentary accommodation space with the coincident formation of the Queen Charlotte Trough (Fig. 12). Sedimentary loading in the trough and tectonic thickening of the QCT contributed to flexure as convergence progressed, and this load continued to depress the Pacific plate as it translated past the bend in the QCF into a strike-slip regime. Through flexural modeling, Prims et al. (1997, with a correction by Rohr et al., 2000) accounted for all of the observed plate flexure at $\sim 54^{\circ} \mathrm{N}$ with sedimentary loading from the Queen Charlotte Terrace and Trough. Our observations are compatible with these models, though we suggest (based on diminishing flexure to the northward of $54^{\circ} \mathrm{N}$ ) that underthrusting initiated the downwarping and creation of accommodation space necessary for accumulation of a sediment load. Although sedimentary loading is our preferred interpretation to explain the preservation of flexure 
north of $53.2^{\circ} \mathrm{N}$, we acknowledge the possibility that small amounts of convergence ( $\sim 5^{\circ}$ angle) north of $53.2^{\circ} \mathrm{N}$ may play a role in maintaining flexure as well.

Our model suggests that some amount of plate flexure should exist along portions of the Pacific plate that have been exposed to convergence. The present day signature of plate flexure may be overprinted at the Kodiak-Bowie seamounts, as we observe crustal shallowing where the bathymetric high of the seamount chain crosses the Queen Charlotte Trough. A study by Harris and Chapman (1994) discusses the superimposed effects of the geodynamic influences of the KodiakBowie seamounts and the sediment-filled trough, though their study only utilized gravity and bathymetry data; in this study, we include observations of seismic reflection profiles. The Kodiak-Bowie seamounts were likely emplaced on young, thin crust, suggesting formation at a spreading ridge (Turner et al., 1980; Harris and Chapman, 1994) that could generate a fairly wide swath of seamounts (Fig. 10). Though the age is unconstrained, we assume the seamount that we image in the Queen Charlotte Trough (Fig. 7) was generated at a ridge and is similar in age to the surrounding crust; despite this, we do not observe obvious flexure here. It is possible that the locally thicker and more buoyant crust of the Kodiak-Bowie seamounts may have resisted underthrusting and/or blocked propagation of flexure to the south (e.g., Christeson et al., 2010; Worthington et al., 2012), though more likely it is simply an overprinting of flexure due to higher topography. We are unable to effectively image and assess flexure around the seamounts with the existing data coverage, however.

We recognize that our interpretation of flexural changes has little constraining data, and that uncertainties allow for alternative explanations. For instance, we assume a plate boundary that remains fixed to North America, but it is probable that the boundary has shifted some through time, directly affecting the amount of convergence along the QCF. Our interpretation is most consistent with the available data, though it is not the only plausible model. Given the uncertainties, we highlight the need to acquire improved imaging along the QCF that could better test the model presented here.

\section{Conclusions}

Our observations put the Queen Charlotte fault into a regional tectonic context that includes recent and historical earthquake ruptures. The QCF changes strike at $53.2^{\circ} \mathrm{N}$, marking an important transition in fault structure and Pacific basement flexure. We propose a conceptual model of the tectonic evolution of the margin since the initiation of convergence along the QCF at $6 \mathrm{Ma}$. The main conclusions of this study of the QCF margin are as follows.

1. We observe landward Pacific plate flexure north of $53.2^{\circ} \mathrm{N}$, with an observed maximum dip of $6^{\circ}$ in the oceanic basement at $54^{\circ} \mathrm{N}$. North and south of here, the Pacific basement shoals along the continental margin. Buried normal faults in the overlying sediment suggest that the upper portion of the plate was extended during bending.

2. We hypothesize that there are two possible segment boundaries along the QCF: one at $56^{\circ} \mathrm{N}$ and the other at $53.2^{\circ} \mathrm{N}$, at the bend in the QCF. Observed plate flexure ends at $\sim 56^{\circ} \mathrm{N}$, which marks the maximum extents of the 1949 and 1972 earthquakes and is consistent with the Craig event's aftershock zone (which also extends to $\sim 56^{\circ} \mathrm{N}$ ). We propose that the $56^{\circ} \mathrm{N}$ boundary is due to the presence of the Aja fracture zone's intersection with the QCF, which also marks an abrupt $\sim 3$ my change of crustal age. The $53.2^{\circ} \mathrm{N}$ boundary is characterized by the bend in the QCF, the Kodiak-Bowie seamounts, and a reduction of Pacific plate flexure south of the boundary, where the $2012 M_{\mathrm{w}} 7.8$ Haida Gwaii event occurred.

3. A tectonic reconstruction suggests that crust exhibiting flexure now located between $54^{\circ}$ and $56^{\circ} \mathrm{N}$ was located along the southern QCF at the initiation of convergence there $\sim 6$ my ago. We interpret the flexure between $54^{\circ}$ and $56^{\circ} \mathrm{N}$ to be a result of past convergence and underthrusting along the obliquely convergent southern QCF, now inactive as the crust has translated past a bend in the QCF into a more strike-slip regime.

4. Normal faulting and stratigraphic unconformities above the Pacific plate suggest that the trough generated by underthrusting was filled with sediment both concurrent with and after active plate flexure. We suggest that flexure was preserved after translation north of the bend in the QCF due to load from the trough sediment, the QCT, and/or the North American plate itself.

5. The model supports the idea that the young Pacific crust along the southern QCF is flexing and beginning to underthrust adjacent to the margin of British Columbia today, and that the recent Haida Gwaii event was caused by these plate interactions. The observations of downwarping and normal faulting along the northern QCF may be a northern analog for the modern process occurring near Haida Gwaii. Better imaging of the QCF fault at the location of the recent Haida Gwaii rupture is required to conclusively define the fault boundaries at depth and to identify a possible thrust surface that may have accommodated seismogenic slip of the 2012 event.

\section{Data and Resources}

Aftershock data were downloaded from the U.S. Geological Survey (USGS) Earthquake Archive Search and URL Builder at http://earthquake.usgs.gov/earthquakes/search/ (last accessed January 2014). Bathymetry data shown in figures in this study are ETOPO1 data available through the National Geophysical Data Center (NGDC) at http://www.ngdc.noaa .gov/mgg/global/global.html (last accessed September 2011). Other bathymetry used in this study includes a United Nations Commission Law of the Sea (UNCLOS) dataset, which can be downloaded at http://ccom.unh.edu/theme/law-sea/law-of-thesea-data/gulf-of-alaska (last accessed May 2011). Coastline 
data are available via the NGDC Coastline Extractor at http:// www.ngdc.noaa.gov/mgg/shorelines/shorelines.html (last accessed October 2012). Craig earthquake ( $M_{\mathrm{w}} 7.5$ event on 5 January 2013) information and parameters can be viewed and downloaded via the USGS at http://comcat.cr.usgs.gov/ earthquakes/eventpage/pde20130105085819330_10\#summary (last accessed October 2014). Earthquake mechanisms for major earthquakes were obtained from USGS at earthquake event pages that can be accessed from http://earthquake.usgs. gov/earthquakes/ (last accessed May 2014). Moment tensors can also be downloaded from the Global Centroid Moment Tensor catalog at http://www.globalcmt.org/CMTsearch. html (last accessed February 2015). Faults mapped prior to this study were obtained from a Geological Society of America database which can be obtained through the USGS here: http://pubs.usgs.gov/ds/424/ (last accessed January 2014). Geological LOng-Range Inclined Asdic (GLORIA) sidescan sonar data can be downloaded via the USGS at http://coastalmap.marine.usgs.gov/gloria/ (last accessed January 2014). Haida Gwaii earthquake ( $M_{\mathrm{w}} 7.8$ event on 28 October 2012) information and parameters can be viewed and downloaded via the USGS at http://comcat.cr.usgs.gov/ earthquakes/eventpage/pde20121028030408820_14\#summary (last accessed January 2014). Plate motion vectors for reconstruction models were calculated using the MORVEL model and the UNAVCO plate motion calculator at http://www. unavco.org/software/geodetic-utilities/plate-motion-calculator/ plate-motion-calculator.html (last accessed May 2014). USGS seismic data displayed in the figures are available through the USGS National Archive of Marine Surveys (http://walrus.wr. usgs.gov/NAMSS; last accessed October 2013). Though not displayed in figures in this article, survey EW9412 can be obtained as raw, unprocessed data from the Academic Seismic Portal at Lamont Doherty Earth Observatory (http://www. marine-geo.org/portals/seismic; last accessed December 2013); stacked and migrated sections can also be obtained in SEGY format from the Academic Seismic Portal at the University of Texas Institute for Geophysics (UTIG) (http://www.ig.utexas. edu/sdc; last accessed February 2015). Software resources used for analysis included Halliburton's Landmark DecisionSpace Desktop module (https://www.landmarksoftware.com/; last accessed February 2015), Esri's ArcGIS Desktop (http:// www.esri.com/software/arcgis; last accessed February 2015), and GPlates plate reconstruction software (http://www. gplates.org; last accessed February 2015). All other data discussed in this study came from published sources listed in the references.

\section{Acknowledgments}

We would like to extend our thanks to Kristin Rohr, John Swartz, and Harm Van Avendonk for helpful scientific discussion and feedback and to Ray Sliter and Steffen Saustrup for assistance with legacy seismic data. Thanks to the U.S. Geological Survey (USGS) for providing much of the legacy data, to Anne Tréhu for providing data from survey EW9412, and to the computing facilities and systems administrators at University of Texas Institute for Geophysics (UTIG). In addition, our thanks go to the two reviewers and Guest Editor Tom James for their helpful and relevant comments, which have greatly improved the clarity of the text and figures. This project was funded in part by the USGS Earthquake Hazards External Grants Program, the National Earthquake Hazards Reduction Program, and the UTIG Ewing/ Worzel Fellowship. This is UTIG Contribution Number 2790.

\section{References}

Amante, C., and B. W. Eakins (2009). ETOPO1 1 Arc-Minute Global Relief Model: Procedures, Data Sources and Analysis, U.S. Department of Commerce, National Oceanic and Atmospheric Administration, National Environmental Satellite, Data, and Information Service, National Geophysical Data Center, Marine Geology and Geophysics Division, NOAA Technical Memorandum NESDIS NGDC-24.

Atwater, T. (1970). Implications of plate tectonics for the Cenozoic tectonic evolution of western North America, Bull. Geol. Soc. Am. 81, no. 12, 3513-3536.

Barrie, J. V., K. W. Conway, and P. T. Harris (2013). The Queen Charlotte fault, British Columbia: Seafloor anatomy of a transform fault and its influence on sediment processes, Geo Mar. Lett. 33, 1-8.

Bérubé, J., G. C. Rogers, R. M. Ellis, and E. O. Hasselgren (1989). A microseismicity study of the Queen Charlotte Islands region, Can. J. Earth Sci. 26, no. 12, 2556-2566.

Bostwick, T. K. (1984). A re-examination of the August 22, 1949 Queen Charlotte earthquake, M.S. Thesis, The University of British Columbia, Vancouver, British Columbia, 126 pp.

Botros, M., and H. P. Johnson (1988). Tectonic evolution of the Explorernorthern Juan de Fuca region from 8 Ma to the present, J. Geophys. Res. 93, no. B9, 10,421-10,437.

Bruns, T. R., A. J. Stevenson, and M. R. Dobson (1992). GLORIA Investigation of the Exclusive Economic Zone in the Gulf of Alaska and Off Southeast Alaska: M/V Farnella Cruise F7-89-GA, June 14-July 13, 1989, U.S. Department of the Interior, U.S. Geol. Surv. Open-File Rept. 92-317, 16 pp.

Bustin, A., R. Hyndman, H. Kao, and J. Cassidy (2007). Evidence for underthrusting beneath the Queen Charlotte margin, British Columbia, from teleseismic receiver function analysis, Geophys. J. Int. 171, no. 3, 1198-1211.

Carbotte, S. M., J. M. Dixon, E. Farrar, E. E. Davis, and R. P. Riddihough (1989). Geological and geophysical characteristics of the Tuzo Wilson seamounts: Implications for plate geometry in the vicinity of the Pacific-North American-Explorer triple junction, Can. J. Earth Sci. 26, no. 11, 2365-2384.

Carlson, P. R., T. R. Bruns, and G. Plafker (1988). Late Cenozoic offsets on the offshore connection between the Fairweather and Queen Charlotte faults off southeast Alaska, Mar. Geol. 85, no. 1, 89-97.

Carlson, P. R., G. Plafker, and T. R. Bruns (1985). Map and selected seismic profiles of the seaward extension of the Fairweather fault, eastern Gulf of Alaska, U.S. Geological Survey Miscellaneous Field Studies Map 1722,2 sheets.

Chase, R., and D. Tiffin (1972). Queen Charlotte fault zone, British Columbia, Mar. Geol. Geophys. 8, 17-27.

Christeson, G. L., S. P. S. Gulick, H. van Avendonk, R. S. Reece, and L. L. Worthington (2010). The Yakutat terrane: Dramatic change in crustal thickness across the Transition fault, Alaska, Geology 38, no. 10, 895-898.

Crouch, J. K., S. B. Bachman, and J. T. Shay (1984). Post-Miocene compressional tectonics along the central California margin, in Tectonics and Sedimentation along the Central California Margin, Pacific Section of Society of Economic Paleontologists and Mineralogists, Vol. 38, 37-54.

Davis, E. E., and D. A. Seemann (1981). A compilation of seismic reflection profiles across the continental margin of western Canada, Geol. Surv. Canada Open-File Rept. 751.

Dehler, S. A., and R. M. Clowes (1988). The Queen Charlotte Islands refraction project. Part I. The Queen Charlotte fault zone, Can. J. Earth Sci. 25, no. 11, 1857-1870.

DeMets, C., R. G. Gordon, and D. F. Argus (2010). Geologically current plate motions, Geophys. J. Int. 181, no. 1, 1-80. 
Ding, K., J. T. Freymueller, Q. Wang, and R. Zou (2015). Coseismic and early postseismic deformation of the 5 January 2013 Craig $M_{\mathrm{w}} 7.5$ earthquake from GPS static and kinematic solutions, Bull. Seismol. Soc. Am. 105, no. 2B, doi: 10.1785/0120140172.

Doubrovine, P. V., and J. A. Tarduno (2008). A revised kinematic model for the relative motion between Pacific oceanic plates and North America since the Late Cretaceous, J. Geophys. Res. 113, no. B12, B12101.

Ekström, G., M. Nettles, and A. Dziewoński (2012). The global CMT project 2004-2010: Centroid-moment tensors for 13,017 earthquakes, Phys. Earth Planet. In. 200, 1-9.

Elliott, J. L., C. F. Larsen, J. T. Freymueller, and R. J. Motyka (2010). Tectonic block motion and glacial isostatic adjustment in southeast Alaska and adjacent Canada constrained by GPS measurements, J. Geophys. Res. 115, no. B9, B09407, doi: 10.1029/2009JB007139.

Farahbod, A. M., and H. Kao (2015). Spatiotemporal distribution of events during the first week of the 2012 Haida Gwaii aftershock sequence, Bull. Seismol. Soc. Am. 105, no. 2B, doi: 10.1785/0120140173.

Fletcher, H. J., and J. T. Freymueller (2003). New constraints on the motion of the Fairweather fault, Alaska, from GPS observations, Geophys. Res. Lett. 30, no. 3, 1139.

Freymueller, J. T., M. H. Murray, P. Segall, and D. Castillo (1999). Kinematics of the Pacific-North America plate boundary zone, northern California, J. Geophys. Res. 104, no. B4, 7419-7441.

Gardner, J. V., L. A. Mayer, and A. Armstrong (2006). Mapping supports potential submission to U.N. Law of the Sea, Eos Trans. AGU 87, 157-160.

Gulick, S. P. S., L. A. Lowe, T. L. Pavlis, J. V. Gardner, and L. A. Mayer (2007). Geophysical insights into the Transition fault debate: Propagating strike slip in response to stalling Yakutat block subduction in the Gulf of Alaska, Geology 35, no. 8, 763-766.

Haeussler, P. J., D. C. Bradley, R. E. Wells, and M. L. Miller (2003). Life and death of the Resurrection plate: Evidence for its existence and subduction in the northeastern Pacific in Paleocene-Eocene time, Bull. Geol. Soc. Am. 115, no. 7, 867-880.

Harris, R. N., and D. S. Chapman (1994). A comparison of mechanical thickness estimates from trough and seamount loading in the southeastern Gulf of Alaska, J. Geophys. Res. 99, no. B5, 9297-9317.

Hyndman, R., and R. Ellis (1981). Queen Charlotte Fault zone: Microearthquakes from a temporary array of land stations and ocean bottom seismographs, Can. J. Earth Sci. 18, no. 4, 776-788.

Hyndman, R., and T. Hamilton (1993). Queen Charlotte area Cenozoic tectonics and volcanism and their association with relative plate motions along the northeastern Pacific margin, J. Geophys. Res. 98, no. B8, $14,257-14,277$.

Hyndman, R., T. Lewis, J. Wright, M. Burgess, D. Chapman, and M. Yamano (1982). Queen Charlotte fault zone: Heat flow measurements, Can. J. Earth Sci. 19, no. 8, 1657-1669.

James, T., G. Rogers, J. Cassidy, H. Dragert, R. Hyndman, L. Leonard, L. Nykolaishen, M. Riedel, M. Schmidt, and K. Wang (2013). Field studies target 2012 Haida Gwaii earthquake, Eos Trans. AGU 94, no. 22, 197-198.

Kao, H., S.-J. Shan, and A. M. Farahbod (2015). Source characteristics of the 2012 Haida Gwaii earthquake sequence, Bull. Seismol. Soc. Am. 105, no. 2B, doi: $10.1785 / 0120140165$.

King, G., and J. Nábělek (1985). Role of fault bends in the initiation and termination of earthquake rupture, Science 228, no. 4702, 984-987.

Lay, T., L. Ye, H. Kanamori, Y. Yamazaki, K. F. Cheung, K. Kwong, and K. D. Koper (2013). The October 28, $2012 M_{\mathrm{w}} 7.8$ Haida Gwaii underthrusting earthquake and tsunami: Slip partitioning along the Queen Charlotte fault transpressional plate boundary, Earth Planet. Sci. Lett. $375,57-70$.

Leonard, L., and J. Bednarski (2014). Field survey following the 28 October 2012 Haida Gwaii tsunami, Pure Appl. Geophys. 171, 1-16.

Mackie, D., R. Clowes, S. Dehler, R. Ellis, and P. Morel-À-l'Huissier (1989). The Queen Charlotte Islands refraction project. Part II. Structural model for transition from Pacific plate to North American plate, Can. J. Earth Sci. 26, no. 9, 1713-1725.
Masson, D. (1991). Fault patterns at outer trench walls, Mar. Geophys. Res. 13, no. 3, 209-225.

Maus, S., U. Barckhausen, H. Berkenbosch, N. Bournas, J. Brozena, V. Childers, F. Dostaler, J. D. Fairhead, C. Finn, R. R. B. von Frese, et al. (2009). EMAG2: A 2-arc min resolution Earth Magnetic Anomaly Grid compiled from satellite, airborne, and marine magnetic measurements, Geochem. Geophys. Geosyst. 10, no. 8, Q08005, doi: 10.1029/2009GC002471, ISSN: 1525-2027.

Morozov, I. B., S. B. Smithson, L. S. Hollister, and J. B. Diebold (1998). Wide-angle seismic imaging across accreted terranes, southeastern Alaska and western British Columbia, Tectonophysics 299, no. 4, 281-296.

Müller, R. D., W. R. Roest, J.-Y. Royer, L. M. Gahagan, and J. G. Sclater (1997). Digital isochrons of the world's ocean floor, J. Geophys. Res. 102, no. B2, 3211-3214.

Nykolaishen, L., H. Dragert, K. Wang, T. James, and M. Schmidt (2015). GPS observations of crustal deformation associated with the $M_{\mathrm{w}} 7.7$ 2012 Haida Gwaii earthquake, Bull. Seismol. Soc. Am. 105, no. 2B, doi: 10.1785/0120140177.

Plafker, G., L. M. Gilpin, and J. C. Lahr (1994). Neotectonic map of Alaska, Geol. North Am. 1, 389-449.

Plafker, G., T. Hudson, T. Bruns, and M. Rubin (1978). Late Quaternary offsets along the Fairweather fault and crustal plate interactions in southern Alaska, Can. J. Earth Sci. 15, no. 5, 805-816.

Prims, J., K. Furlong, K. Rohr, and R. Govers (1997). Lithospheric structure along the Queen Charlotte margin in western Canada: Constraints from flexural modeling, Geo Mar. Lett. 17, no. 1, 94-99.

Rabinovich, A. B., R. E. Thomson, V. V. Titov, F. E. Stephenson, and G. C. Rogers (2008). Locally generated tsunamis recorded on the coast of British Columbia, Atmosphere-Ocean 46, no. 3, 343-360.

Raymo, M. E. (1994). The initiation of northern hemisphere glaciation, Ann. Rev. Earth Planet. Sci. 22, 353-383.

Reed, J. C., J. O. Wheeler, and B. E. Tucholke (2005). Decade of North American Geology: Geologic Map of North America: Perspectives and Explanation, Geological Society of America, Boulder, Colorado.

Ristau, J., G. C. Rogers, and J. F. Cassidy (2007). Stress in western Canada from regional moment tensor analysis, Can. J. Earth Sci. 44, no. 2, $127-148$.

Rogers, G. C. (1986). Seismic gaps along the Queen Charlotte fault, Earthq. Pred. Res. 4, nos. 1/2, 1-11.

Rohr, K. M. M. (2015). Plate boundary adjustment of the southernmost Queen Charlotte fault, Bull. Seismol. Soc. Am. 105, no. 2B, doi: 10.1785/0120140162.

Rohr, K. M. M., and K. P. Furlong (1995). Ephemeral plate tectonics at the Queen Charlotte triple junction, Geology 23, no. 11, 1035-1038.

Rohr, K. M. M., M. Scheidhauer, and A. M. Trehu (2000). Transpression between two warm mafic plates: The Queen Charlotte Fault revisited, J. Geophys. Res. 105, no. B4, 8147-8172.

Sandwell, D., E. Garcia, K. Soofi, P. Wessel, M. Chandler, and W. H. Smith (2013). Toward 1-mGal accuracy in global marine gravity from CryoSat-2, Envisat, and Jason-1, TLE 32, no. 8, 892-899.

Scheidhauer, M. (1997). Crustal structure of the Queen Charlotte transform fault zone from multi-channel seismic reflection and gravity data, M.S. Thesis, Oregon State University, $184 \mathrm{pp}$.

Scheidhauer, M., A. M. Trehu, and K. M. M. Rohr (1999). Multichannel seismic reflection survey over the northern Queen Charlotte fault, Geol. Surv. Canada Open-File Rept. 3779.

Schell, M. M., and L. J. Ruff (1989). Rupture of a seismic gap in southeastern Alaska: The 1972 Sitka earthquake $\left(M_{\mathrm{s}}\right.$ 7.6), Phys. Earth Planet. In. 54, no. 3, 241-257.

Seton, M., R. Müller, S. Zahirovic, C. Gaina, T. Torsvik, G. Shephard, A. Talsma, M. Gurnis, M. Turner, and S. Maus (2012). Global continental and ocean basin reconstructions since $200 \mathrm{Ma}$, Earth Sci. Rev. 113, no. $3,212-270$.

Smith, A., R. Hyndman, J. Cassidy, and K. Wang (2003). Structure, seismicity, and thermal regime of the Queen Charlotte transform margin, J. Geophys. Res. 108, no. B11, doi: 10.1029/2002JB002247. 
Snavely, P. D., H. D. Wagner, D. H. Tompkins, and D. L. Tiffin (1981) Preliminary geologic interpretation of a seismic reflection profile across the Queen Charlotte Island fault system off Dixon Entrance, Canada-United States, Geol. Surv. Canada Open-File Rept. 81-299.

Sykes, L. R. (1971). Aftershock zones of great earthquakes, seismicity gaps, and earthquake prediction for Alaska and the Aleutians, J. Geophys. Res. 76, no. 32, 8021-8041.

Tobin, D. G., and L. R. Sykes (1968). Seismicity and tectonics of the northeast Pacific Ocean, J. Geophys. Res. 73, no. 12, 3821-3845.

Tocher, D. (1960). The Alaska earthquake of July 10, 1958: Movement on the Fairweather fault and field investigation of southern epicentral region, Bull. Seismol. Soc. Am. 50, no. 2, 267-292.

Tréhu, A. M., M. Scheidhauer, M. A. L. Walton, S. Gulick, E. Roland, and B. Tikoff (2015). An abrupt transition in the mechanical response of the upper crust to transpression across the Queen Charlotte fault, Bull. Seismol. Soc. Am. 105, no. 2B, doi: 10.1785/0120140159.

Turner, D., R. Jarrard, and R. Forbes (1980). Geochronology and origin of the Pratt-Welker seamount chain, Gulf of Alaska: A new pole of rotation for the Pacific plate, J. Geophys. Res. 85, no. B11, 6547-6556.

von Huene, R., G. G. Shor Jr., and J. Wageman (1979). Continental margins of the eastern Gulf of Alaska and boundaries of tectonic plates, Geological and geophysical investigations of continental margins, American Association of Petroleum Geologists Memoir, Vol. 29, 273-290.

Walton, M. A., S. P. Gulick, R. S. Reece, G. A. Barth, G. L. Christeson, and H. J. Van Avendonk (2014). Dynamic response to strike-slip tectonic control on the deposition and evolution of the Baranof fan, Gulf of Alaska, Geosphere 10, no. 4, 680-691.

Wang, K., and S. L. Bilek (2011). Do subducting seamounts generate or stop large earthquakes? Geology 39, no. 9, 819-822.

Wang, K., J. He, F. Schulzeck, R. Hyndman, and M. Riedel (2015). Thermal condition of the 27 October $2012 M_{\mathrm{w}} 7.8$ Haida Gwaii subduction earthquake at the obliquely convergent Queen Charlotte margin, Bull. Seismol. Soc. Am. 105, no. 2B, doi: 10.1785/0120140183.

Wesnousky, S. G. (2006). Predicting the endpoints of earthquake ruptures, Nature 444, no. 7117, 358-360.

Wilson, D. S. (2002). The Juan de Fuca plate and slab: Isochron structure and Cenozoic plate motions, U.S. Geol. Surv. Open-File Rept. 02-328, $9-12$.
Worthington, L. L., H. J. A. Van Avendonk, S. P. S. Gulick, G. L. Christeson, and T. L. Pavlis (2012). Crustal structure of the Yakutat terrane and the evolution of subduction and collision in southern Alaska, J. Geophys. Res. 117, no. B1, B01102, doi: 10.1029/2011JB008493.

Institute for Geophysics

Jackson School of Geosciences

The University of Texas at Austin

J.J. Pickle Research Campus Building ROC-196

10100 Burnet Road

Austin, Texas 78758-4445

maureenlwalton@utexas.edu

(M.A.L.W., S.P.S.G.)

U.S. Geological Survey

4210 University Dr

Anchorage, Alaska 99508

(P.J.H.)

University of Washington

School of Oceanography, Box 357940

Seattle, Washigton 98195-7940

(E.C.R.)

The College of Earth, Ocean, and Atmospheric Sciences Oregon State University

104 CEOAS Admin Building

101 Southwest 26th Street

Corvallis, Oregon 97331-5503

(A.M.T.)

Manuscript received 14 June 2014;

Published Online 14 April 2015 